This manuscript is an EarthArXiv preprint. The manuscript has yet to be formally accepted for publication. Subsequent versions of this manuscript may contain some different content. If accepted, the final version of this manuscript will be available via the Peer-reviewed Publication DOI link on the right-hand side of this webpage. Please feel free to contact any of the authors; we welcome feedback. 


\title{
Tidal bar accretion by mudflat sedimentation
}

\author{
L. Braat ${ }^{1 *}$ \\ W. M. van Dijk ${ }^{1}$ \\ H. J. Pierik ${ }^{1}$ \\ W. I. van de Lageweg $^{1,2}$ \\ M. Z. M. Brückner ${ }^{1}$ \\ F. Wagner-Cremer ${ }^{1}$ \\ M. G. Kleinhans ${ }^{1}$ \\ ${ }^{1}$ Faculty of Geosciences, Utrecht University, Utrecht, the Netherlands \\ ${ }^{2}$ HZ University of Applied Sciences, Delta Academy, Groene Woud 1-3, 4331 NB, \\ Middelburg, the Netherlands
}

\begin{abstract}
Mud plays a pivotal role in estuary ecology and morphology. Effects of mud are often ignored in morphodynamic studies due to longer computational times and limited field data. This study aims to understand the spatial distribution of mud layers in tidal bars, their formative conditions, preservation potential and their effects on the morphology of tidal bars in high-energy, sand-dominated estuaries. We use complementary numerical modelling outcomes of a Delft3D schematisation, and field data, including historic bathymetry, biomorphological maps and sediment cores, of a tidal bar (shoal of Walsoorden) in the Western Scheldt, the Netherlands. We distinguish two types of mud layers: 1) drapes, 2-20 mm thick buried layers that are preserved under high energy conditions; and 2) thick beds, $>10 \mathrm{~cm}$ layers at the surface associated with high elevations and slow accumulation. We conclude that mud accumulation is mostly controlled by elevation, flow velocity and flow field. Specifically, mudflats accumulate mainly on the highest landward side of the shoal just after high water slack, shielded from high flood velocities. Mud accumulation increases shoal elevation, potentially to supratidal levels, providing a positive hydrodynamic feed by further reducing flow over the shoal, decreasing chute channels, stabilising the bar and decreasing tidal prism. This supports more mud deposition and eventually vegetation settling. While mud cover at the surface is relatively high (20-40\%), only a small percentage is preserved in the stratigraphy $(\sim 5 \%)$. Due to this preservation bias, interpretations of estuary stratigraphy risk underestimating the importance of mud at the surface.
\end{abstract}

\section{Introduction}

Over the past few decades, estuary management has not only been focussing on flood protection and navigation anymore, but also on nature and ecosystem

*lisannebraat@gmail.com 
services. This has increased the interest in mud (clay + silt $<64 \mu m$ ), which plays a pivotal role in ecological valuable areas. Areas that are low in dynamics, with low flow velocities and muddy substrate, are favoured by most estuarine species (vegetation, benthos and therefore birds) (e.g. Dyer et al., 2000; Singer et al., 2016). In addition, mud affects bed quality by attracting nutrient and/or pollutants and in large quantities decreases light in the water column leading to reduced primary production (Kromkamp et al., 1995). Also non-ecologic effects are of interest as mud can cause problems by siltation in harbours and navigation channels (van Kessel et al., 2011) and mud layers can have a large influence on the morphology of estuaries (Braat et al., 2017, 2018). The latter is often neglected in morphological modelling of estuaries due to model simplifications (e.g. Hibma et al., 2003; van der Wegen \& Roelvink, 2012) with the exception of some models breaking new ground (e.g. van Ledden, Wang, et al., 2004; Waeles et al., 2007; Sanford, 2008; Le Hir et al., 2011; Dam \& Bliek, 2013). A better understanding and predictive capabilities about the distribution of mud are necessary for sustainable estuary management.

Sand and mud distributions in the substrate often show large horizontal and vertical variations due to sand-mud segregation. This is due to different erosion and deposition characteristics of mud compared to sandy or silty sediments. Mud typically needs low velocities to accumulate, but due to the cohesion properties of mud layers (and also mixed sediments, van Ledden, van Kesteren, \& Winterwerp, 2004), they have a high critical shear stress for erosion, i.e. the scour lag effect (van Straaten \& Kuenen, 1957). Because of these characteristics, mudflats generally develop on the fringes of estuaries (Dalrymple \& Choi, 2007) and mud deposition increases with distance from channels (van Straaten \& Kuenen, 1957). This is especially visible in tide-dominated systems when the intertidal area is large. Facies descriptions of intertidal deposits from different estuaries, like the Severn (Allen, 1990), Salmon river estuary (Dalrymple et al., 1991; Dalrymple \& Choi, 2007) and the Bristol channel (Harris \& Collins, 1988) show this large scale distribution of mud in estuaries. Mud predominantly occurs on high intertidal elevations (Allen, 1990).

Not only the lateral distribution of mud is of interest, also the depositional record contains information about past conditions of the system (van de Lageweg et al., 2018). However, only part of the originally deposited sediment is preserved in the geological record due to erosion. This happens either during the same tide (de Boer et al., 1989), spring-neap or seasonal cyclicity (Herman et al., 2001; van der Wal et al., 2010), during large events or during channel migration, causing sediment reworking or even export from the system. Additionally, sedimentation rates strongly differ spatially, This means that the record only represents a small amount of time over which physical processes occurred and not all processes are completely captured (Jerolmack \& Paola, 2010; Davis Jr, 2012; Paola et al., 2018). Results from numerical models and the study of currently active estuaries that we understand are important to better understand the processes behind the preservation of mud, which is relevant to make more appropriate geological reconstructions in the future.

Previous research has shown that mud can reduce estuary size and width 
by confining the estuary on long timescales of centuries to millennia (Braat et al., 2017, 2018). Mudflats flank the estuary and limit lateral migration and expansion of channels. Effects of mud do not only occur laterally, but including mud also increases the height of intertidal flats (Braat et al., 2017, 2018), which can create a window of opportunity for pioneer marsh vegetation (Cao et al., 2017; de Haas et al., 2018). These mud deposits do not only accumulate on the flanks of the estuary, but sometimes occur on the top of intertidal bars within the estuary as well, which is supported by field samples (McLaren, 1994) and remote sensing (van der Wal et al., 2010) for the Western Scheldt.

Despite its importance, mud and its effects are often neglected in morphological modelling due to difficult calibration, limited data and long computational time. The studies that do include mud in morphological models focus mainly on lateral distribution trends at the surface and neglect the analysis of the stratigraphy (van Ledden, Wang, et al., 2004; Waeles et al., 2007; Le Hir et al., 2011; Braat et al., 2017). However, these models also store information about the vertical distribution of mud. Due to this knowledge gap, it is still unclear how mud layers form, preserve and affect the morphology of tidal bars. This can largely affect ecology, morphological predictions, geological interpretations and estuary management.

Here we study the 3D mud distribution in tidal bars, its causes and effects in more detail. We aim to determine: (1) the location and the conditions of mud deposition; (2) how mud layers are preserved in the stratigraphy; and (3) what the implications are for the morphodynamics of the shoal and extrapolate this to estuary scale, for which we focus on high-energy, sand-dominated estuaries. This will contribute to create a better understanding of the formative conditions of mudflats on shoals, the preservation potential of mud and the effect of mud on estuary morphology. In order to gain such understanding, physics-based numerical morphological modelling and field data are combined with concepts and methods of sedimentology.

In this research we use the term shoal to describe our study area, since the study site is called the Shoal of Walsoorden, while we use the term tidal bar, to describe our study site in stratigraphic and geological context. The term mudflat is used to describe the smaller-scale, more surficial morphological and sedimentological unit consisting dominantly of mud in the intertidal regime. By this definition, mudflats can occur on top of shoals and are part of the tidal bar.

The setup of the paper is as follows: First, we will describe the study area, after which we summarise the available data and introduce the numerical model. Next, the results of the field study and model study are described and compared. Last, we will discuss the combined results and their implications.

\section{Site description: Walsoorden, Western Scheldt}

The Scheldt estuary is located at the border of the Netherlands and Belgium. It is the last remaining estuary on the West coast of the Netherlands that has not been (semi-)closed off naturally or by the Delta Works. This is because it is 
the access point to the Port of Antwerp, the second largest harbour in Europe.

The Western Scheldt is a young estuary that developed when the Honte tidal channel expanded landward in the Middle Ages during storm surges, eventually connecting to the Scheldt river (van der Spek, 1997; Pierik et al., 2017; de Haas et al., 2018). After the connection in the $17^{\text {th }}$ century, the Scheldt river could drain via the Western Scheldt tidal system, that became deeper and wider as a result (van der Spek, 1997). The estuary had an irregular planform (van den Berg et al., 1996), with secondary branches to which large amounts of fine sediments were imported, causing accretion of tidal flats and marshes. These secondary branches were embanked stepwise during the last centuries, making the estuarys outline more smooth causing the tidal range and average depth to increase (van den Berg et al., 1996; van der Spek, 1997). The increase in these energy conditions over the last centuries is reflected in the deposits; secondary branches are muddy, while modern deposits are predominantly sandy (van den Berg et al., 1996).

The present-day Western Scheldt is a tide-dominated, semi-diurnal, wellmixed, macrotidal estuary with a tidal range at the mouth of about $4 \mathrm{~m}$ which increases landward up to $5.5 \mathrm{~m}$ at Rupelmonde, $110 \mathrm{~km}$ from the mouth. The discharge of the Scheldt river is approximately $100 \mathrm{~m}^{3} / \mathrm{s}$, which is (integrated over 12 hours) less than $1 \%$ of the tidal prism $\left(2 \cdot 10^{9} \mathrm{~m}^{3}\right.$, Wang et al., 2002). The Scheldt estuary is a mostly sandy estuary and very sandy compared to other estuaries, with a median grain size for sand of about $200 \mu \mathrm{m}$ (McLaren, 1994). Although the estuary is now embanked and steered by large amounts of dredging and dumping (Santermans, 2013), the shape of the estuary is historically largely self-formed and was not influenced by geological constraints, except for some erosion resistance layers (Dam, 2013). The shape of the estuary has a typical exponential convergent shape (Lanzoni \& D'Alpaos, 2015; Savenije, 2015) with some variations in width deviating from this trend, typical for alluvial estuaries (Leuven et al., 2018).

Even though the Western Scheldt is dominantly sandy, mud is an essential member of this system. In the years before significant human interference (1860-1955), the system imported $0.5-1.5$ million $\mathrm{m}^{3}$ clay per year, while $1.4-$ 2.4 million $\mathrm{m}^{3}$ sand was exported per year (Dam \& Bliek, 2017). Mud is therefore very important with regard to the sediment balance. However, the total sediment volume of clay in the current estuary substrate is estimated to be only $5 \%$ (van de Lageweg et al., 2018). The mineralogy of the clay is 40-49\% Illite, $33-42 \%$ smectite, $12-15 \%$ kaolinite and $3-5 \%$ chlorite, with $2-25$ wt\% organic carbon (Griffioen et al., 2016). On a large-scale resolution the average thickness of clay layers is $1.2 \mathrm{~m}$ in the Western Scheldt and they are more abundant towards the flanks of the estuary and at the surface (van de Lageweg et al., 2018). Typical suspended particulate matter (SPM) concentrations in the study area are between 30-60 mg/l (Rijkswaterstaat, 2017, Fig. 16), with median settling velocities of $0.1-0.2 \mathrm{~mm} / \mathrm{s}$ up to a maximum of $0.7 \mathrm{~mm} / \mathrm{s}$ (Winterwerp et al., 1993). The measuring station of Hansweert, closest to Walsoorden, measures a median concentration of $\sim 40 \mathrm{mg} / \mathrm{l}$ (Fig. 16).

We chose this study area, because the Western Scheldt is one of the most 
well-studied and monitored estuaries in the world. In addition to recent data, much historical data (e.g. bathymetry, sediment dynamics, and hydrodynamics) are available. Additionally, the estuary is completely alluvial (i.e. developed in loose sediment) and was easily accessible for fieldwork. The shoal of Walsoorden was chosen because it is a good representation of an average bar in a sandy estuary: it contains mudflats and marshes, is located in the middle of the estuary, approximately $50 \mathrm{~km}$ from the coast and past field visits to this location sparked our interest. Because the shoal is very dynamic, it might show responses to more stable mud layers over short time scales. At Walsoorden, water level ranges from $-2.5-3 \mathrm{~m}$ during spring tide and $-2-2 \mathrm{~m}$ during neap tide (station Walsoorden Rijkswaterstaat, 2017) and the typical salinity around Walsoorden ranges from 15-20 ppt (station Baalhoek Rijkswaterstaat, 2017). Wave energy is almost zero near Walsoorden due to its distance from the mouth (Chen et al., 2005). It is only influenced by locally generated wind waves which can have a large effect on morphology of tidal bars (Maan et al., 2018), but the fetch of the dominant wind is very small for Walsoorden. Although a lot of coring data exist of the Western Scheldt, about 756 cores in the modern day Scheldt region (stored in DINO database, as shown in van de Lageweg et al., 2018), the spacing between cores is quite large, and the vertical intervals in which they are described is low (decimetres). Of all of these 756 cores, only one is located on the shoal of Walsoorden.

\section{Methodology and materials}

In this study we use complementary numerical hydro-morphological modelling results in Delft3D and field data of the shoal of Walsoorden in the Western Scheldt (Fig. 1). The model setup includes sand and mud and a module that builds stratigraphy. The field data includes historic bathymetries, biomorphological classification maps and coring data from a field campaign in October 2017. The studied sediments are all very recent and self-formed by the estuary, up to possibly 1000 years. However, the shoal of Walsoorden only developed about 30 years ago when two smaller shoals grew together. Since we have data of mud for the past 20 years, we focus on the past two decades because this will help us better understand the system, validate the model and add value to our conclusions. With both numerical modelling and field data, we can observe the spatial distribution of mud from field data, while the data also validates the model. The model will help to further interpret the conditions and processes

of deposition and preservation as well as quantify the importance of mud layers on the morphodynamics.

\subsection{Existing data from Walsoorden}

To quantify the spatial distribution of mud over time we used ecotope maps, which are biomorphological maps that were readily available for the years 1996, 2001, 2004, 2008, 2010, 2011, 2012 and 2016. These maps are constructed 
by visual classification of aerial photography with ground truthing and tidal zonation based on bathymetry (Paree \& Burgers, 2017). The maps contain classes that are typically of interest to evaluate the amount of ecological valuable area. Amongst other things, the maps contain mud rich sediment classes and vegetation classes, which were grouped in our analysis as an indicator for mud. The vegetation classes were included, because field observation showed that everywhere where vegetation grows, mud is also present.

Bathymetries were used of the years corresponding to the biomorphological maps. The gridded bathymetries are a combination of echosounding, the 'vaklodingen (20 m resolution) and laser altimetry on the intertidal areas (2$5 \mathrm{~m}$ resolution), which were available for all years except for 1996, for which no laser altimetry was available yet, only vaklodingen. All bathymetry and biomorphological maps were made available by Rijkswaterstaat (Dutch Water Authorities).

In addition to the maps, three profiles of the bar above the low water line were measured regularly from 1991-2017 (Fig. 17). These elevation profiles were measured by Differential GPS by Rijkswaterstaat. On these profiles a few fixed points are located from which soil samples of top $2 \mathrm{~cm}$ and top $10 \mathrm{~cm}$ were analysed regularly. At these locations we have detailed measurements of the mud fraction in the bed (Fig. 17).

\subsection{Acquired data from Walsoorden}

A fieldwork was carried out in October 2017 to gather additional stratigraphic information on the shoal of Walsoorden. During this fieldwork 36 cores (black dots in Fig. 2) up to $3.1 \mathrm{~m}$ depth were taken over a wide variety of environments on the shoal, including marsh, low and high energy tidal-flat environments (Fig. 3). Cores and transects were made using a shovel, gouge auger, van der Staay suction corer or larger suction corer for samples. The cores and transects were photographed and described in the field with and accuracy of $1 \mathrm{~cm}$. Smaller features were ignored or grouped. GPS coordinates (not elevation) of the sample locations were acquired by hand GPS and phone GPS. Throughout the paper we use the Dutch national coordinate system (RD-coordinates, dutch: Rijksdriehoeksmetingen), which is expressed in meters.

Four cores of 45-70 cm long, collected near a big flood channel, were further analysed in the lab because these locations were expected to show small-scale mud layers and diatoms that are indicative of the environmental conditions during deposition. The four retrieved cores were studied in more detail by diatom analysis and sedimentological analysis from lacquer peels (Fig. 4). For diatom analysis, five mud samples were taken from 2 of the 4 cores at different positions in the core (white circles in Fig. 4) that were hypothesised to have a different sedimentary origin based on thickness, sequence, colour and other organic material. In the diatom analysis, different functional groups were identified (benthic, tychoplanktonic and planktonic) and some species and genera indicative for specific environments. The screening did not involve any counting of the diatoms. The lacquer peels, or sediment peels, were made using a 
colourless 210J Flits Coating (similar to the method used in Martinius \& van den Berg, 2011) (Fig. 4). The lacquer peels revealed sedimentary structures of the cores that were not visible on the cores photographs.

\subsection{Building stratigraphy from field data}

Stratigraphy build over the last 20 years (varying thickness per location) was reconstructed by combining mud and vegetation classes from the biomorphological maps and the bathymetries. From old to new, these layers with elevation, lithology and age were stored and combined into an artificial stratigraphy (similar to van de Lageweg et al., 2016). When deposition occurred, information of the older/underlying layers was preserved, however, when erosion occurred in locations all stored layers with a higher bed level than the newer bed layer were removed. Lithology from the field cores was plotted in the reconstruction from the biomorphological maps and bathymetries. Please note that the age coloured transects in Fig. 17 use all available DGPS measured transects of multiple measurements a year, while the transects in Fig. 7 are based on a combination of LiDAR and DGPS elevations and are only shown for the moments in time that biomorphological maps were also available.

\subsection{Model description}

To get more insight in the processes related to the preservation of mud layers we developed a depth averaged (2-DH) morphodynamic model in Delft3D. Delft3D (FLOW2D3D Version 6.02.13.7658M) is a commonly used, validated, open source numerical modelling package (Lesser et al., 2004). The setup of the model is largely based on one domain of the NeVla model (Vroom et al., 2015) of the Western Scheldt (as used in van Dijk, Hiatt, et al., 2018), but has significant alterations due to the inclusion of mud and stratigraphy.

To include mud we use two sediment types, a sand $(200 \mu \mathrm{m})$ and two mud fractions. All characteristics of the mud fractions are the same (Table 1), however, they are supplied from different boundaries to keep track of the origin of the deposited mud (landward or seaward). To keep track of sand and mud in the bed, we use the underlayer module. This module in Delft3D has been available for a couple of years but has not been widely used, yet (van Kessel et al., 2012). We use the underlayer with a Lagrangian active layer concept and Eulerian storage layers (van Kessel et al., 2012) (Table 1). Sand transport is calculated by use of the van Rijn (2007a,b): TRANSPOR2004 equation and mud erosion and deposition is calculated with the so-named Partheniades-Krone formulations (as observed in Partheniades, 1965, Eq. 1 and 2). There is no interaction between sand and mud in the bed, erosion and deposition is handled separately. A very high critical bed shear stress for deposition was chosen (Table. 1) so continuous settling occurs (Sanford \& Halka, 1993). The critical bed shear stress for erosion is in reality largely variable, most importantly due to compaction.

citetwinterwerp1993 showed with flume experiments that the shear strength of a Western Scheldt sediment mixture with $70 \%$ mud is approximately $0.1 \mathrm{~N} / \mathrm{m}^{2}$ 
just after deposition. To account for some compaction we chose a critical shear stress for erosion of $0.2 \mathrm{~N} / \mathrm{m}^{2}$ (Table 1). Bed level change is calculated from the divergence of bedload sediment fluxes and erosion-deposition differences for suspended sediment. To speed up morphodynamic calculation bed level change is multiplied with a morphological acceleration factor of 20 every time step.

$$
\begin{gathered}
E=M S\left(\tau_{c w}, \tau_{c r, e}\right) \\
D=w_{s} c_{b} S\left(\tau_{c w}, \tau_{c r, d}\right)
\end{gathered}
$$

where $\mathrm{E}$ is the erosion flux $\left[\mathrm{kg} \mathrm{m}^{-2} \mathrm{~s}^{-1}\right], \mathrm{M}$ is the defined erosion parameter $\left[\mathrm{kg} \mathrm{m}^{-2} \mathrm{~s}^{-1}\right], \mathrm{S}\left(\tau_{c w}, \tau_{c r, e}\right)$ is the erosion step function, $\mathrm{S}\left(\tau_{c w}, \tau_{c r, d}\right)$ is the deposition step function, D is the deposition flux $\left[\mathrm{kg} \mathrm{m}^{-2} \mathrm{~s}^{-1}\right], \mathrm{w}_{s}$ the settling velocity $[\mathrm{m} / \mathrm{s}]$ and $c_{b}$ the average sediment concentration.

The original NeVla model is already calibrated for water levels and velocities and shows good correlation with measurements (Schrijvershof \& de Vet, 2018); the model therefore does not need any further calibration for hydrodynamics. Sensitivity tests were conducted to obtain the best setting for mud and morphological parameters (Fig. 1) that reproduced patterns observed in the biogeomorphological maps. We only tested settings in the range suggested by field data and similar model studies.

\subsection{Model setup}

The model has a curvilinear grid which extends from Bakendorp to the DutchBelgian border between the dikes (approximately $25 \times 15 \mathrm{~km}$ ). The grid has a median cell size of approximately $64 \times 44 \mathrm{~m}$ (Fig. 5). The model is decomposed into two domains, the outer coarser areas and the inner refined domain. A refinement is used on Walsoorden resulting in a median cell size of $33 \times 40 \mathrm{~m}$. Bathymetry data from Rijkswaterstaat were used for the initial morphology of 1996 and all other initial bathymetries that were tested. The starting year, 1996, corresponds to the oldest available biomorphological dataset. Even though LiDAR (2-5 m resolution) was available from 2001 onward, the grid size did not require this high resolution.

At the two boundaries of the model we used one year of water level boundaries from 2013 obtained from the full NeVla model (van Dijk, Hiatt, et al., 2018), including astronomic tides, storm surges and wave set-up. The same boundary conditions were used for all model runs. Sediment conditions at the boundaries are an equilibrium boundary for sand, meaning that flow entering the domain carries the same concentration as computed within the domain making the gradient perpendicular to the boundary zero. For mud we supply a constant concentration of $40 \mathrm{mg} / \mathrm{L}$ (Table 1, Fig. 16).

The reference scenariois a long-term run of 20 morphological years, based on one year of hydrodynamics. In addition we tested different initial bathymetries with short-term runs of 75 hydrodynamic days (4 morphological years) to 
validate if the mud deposition pattern would hold for different initial morphologies. With the short-term runs, we can compare the spatial distribution of mud more honestly because the bathymetry is more similar to the field data, while the long-term runs provide the possibility to study mud accumulation over time and build stratigraphy. Other scenarios that are included in the paper focus on the sensitivity of different mud parameters in the model: settling velocity, critical bed shear stress for erosion, erosion parameter and input concentration at the boundaries (Table 1). About 100 test and scenarios were conducted in preparation of finding our final model settings, but were not included in this paper.

Model results are visualised similar to the field data in Fig. 6, so the results can be easily compared. Please note that the time interval between maps is therefore not equal, since the interval of biomorphological maps is not consistent. In addition to the long-term and short-term morphological runs, a run of one tidal cycle was done to capture potential dependencies of the mud to the moment in the tidal cycle. Moreover, the hydrodynamics could also be studied in these shorter runs. These studies could not be done with the standard long-term run, because only a limited amount of time steps could be saved due to the file size.

\subsection{Model limitations}

To maintain achievable computational times of the model scenarios, we ignore salinity, 3D velocity patterns, wind, waves, storm events, flocculation and compaction. We assume that our simplifications are reasonable because the estuary is well-mixed and tidal processes dominate sediment transport while the fetch is small and the study site is $50 \mathrm{~km}$ land inwards from the coast. Bed composition dependent roughness is also excluded, since the model is calibrated by roughness. Except for this adapted roughness biological components are ignored. Since physical processes influence the main attributes of mudflats much more than biological processes, this can be justified (Dyer et al., 2000).

\section{Results}

\subsection{Morphological evolution}

Since approximately 1990, Walsoorden has been intensively monitored. The data shows that the morphology of the shoal changed visually over $2-3$ decades. The south-eastern tip of the shoal has been lengthening until 2004 (Fig. 6a-c an Fig. 7a), while narrowing (Fig. 7c, e and g). After 2004, the length of the shoal started to decrease again (Fig. 6c-f and Fig. 7a), while the narrowing continued. The north-western tip of the shoal has generally been quite stable over time, however, a flood channel started to develop from 1990 and the connected elongated bar widened rapidly while the northern flank of the shoal eroded within the flood channel (Fig. 7c and Fig. 17). After 2010, the north-western tip started to increase in elevation (Fig. 7a and Fig. 17a), which can be attributed to the 
dumping of dredged sediment below the low water line, which started at this location around this period.

Additionally, the field data shows that the southern flank of the shoal has a more irregular trend of erosion and deposition compared to the other sides of the shoal, which is shown by the crossing lines on the left side of Fig. 7c and g. This part of the shoal is influenced by shoal margin collapses (van Dijk, Mastbergen, et al., 2018, e.g. in 2012 Fig. 6e). These types of processes are not accounted for in the model in this paper.

Similar initial trends occur in the morphological model as in the field data. The model reproduces the lengthening of the shoal in the landward/upstream direction (Fig. 6g-e). Additionally, narrowing of the shoal occurs by erosion of the south, but mostly north side of the shoal (Fig. 7b, d, f and h). Both the field data and the model show continuous vertical accretion of the shoal (Fig. 7a, b, $\mathrm{c}, \mathrm{f}, \mathrm{g}$ and $\mathrm{h}$ ). An accretion up to $0.5 \mathrm{~m}$ is observed for both data of transect 4 (Fig. 2) between 1996 and 2016. Additionally, the size of the shoal also fluctuates slowly in the same range between 4.5 and $6 \mathrm{~km}^{2}$ (Fig. 9a and b). Over time, the mean-intertidal elevations increased to high-intertidal up to mean high water level, which is visible in the hypsometry of the shoal (Fig. 10a). In the top of Fig. 10a you see the increase in elevation between 1996 and 2016 from blue to red. In total, the model results indicate that $1.64 \cdot 10^{6} \mathrm{~m}^{3}$ sediment has been deposited in the region of interest between 1996 and 2016. Of this volume, $87 \%$ is originated from the western/seaward boundary (or reworked initial mud) and $13 \%$ is originated from the eastern/landward boundary. In summary, the model shows generally realistic behaviour similar to the morphological change of the shoal of Walsoorden (Fig. 6).

The evolution of Walsoorden model shows similar initial trends as the bathymetry data, but gets increasingly divergent with time. Even though the morphology is still realistic, the model does not show the erosion of the south-eastern tip after 2004 (Fig. 7f compared to e) and the north-north-eastern flood channel and small bar are not well represented (Fig. 6). Despite that the north-western tip is relatively stable like in the data, a small bar is growing closely to the tip (Fig. 7a) which is represented in the shoal size in Fig. 9a.

The differences between the model and the field data are attributed to inaccuracies in sediment transport predictors and simplifications, but also largely due to ignoring human interference in the model, mainly dredging and dumping. In the larger model we observe sill formation at the sill of Hansweert: here sand is deposited that in reality is an important dredging location (Plancke et al., 2014; van Dijk et al., 2019). Without dredging, bars form in this location that are normally dredged and influences the landward channel-shoal arrangement and evolution (also observed in van Dijk, Hiatt, et al., 2018), including Walsoorden. This problem at the sill of Hansweert was not dependent on initial bathymetry, since this was tested in model scenarios with other initial bathymetries. Despite differences with the field data, the bar complex still has a realistic morphology with natural slopes, channels and mud cover. 


\subsection{Spatial mud distribution}

According to the field data, mud (and mud with vegetation) is mostly located on the south-eastern side of the shoal (Fig. 6a-f) above mean water level $(+0 \mathrm{~m}$ NAP, Fig. 8a, c and g). The mudflats continue along the northern side of the shoal. In 2001 and 2004 mud spreads more towards the southwest side of the shoal. Since this variation only occurs in these years, this variation might be related to cyclicity with periods shorter than a year (seasonal or spring-neap) or storm conditions. Since all the aerial photographs for these maps were made during low water spring tide, it is more likely attributed to seasons than to spring-neap cyclicity, since the map dates vary by months (Table 3 ).

The distribution of mud in the model is comparable to the field data (Fig. $6 \mathrm{~g}-$ 1). The mud initially settles on high elevations on the eastern side of the shoal, after which the mud spreads to the middle of the shoal towards the west in the years 2001-2009. The deposits in the centre retreat again after this period (Fig. 6j-1), but the deposits on the eastern side are maintained throughout the model run, which is also visible in the field data (Fig. 6).

The vegetated area on the north side is somewhat underrepresented with mud (Fig. 6d-f compared to $\mathrm{j}-\mathrm{l}$ ). In the field we find a relatively thick mud layer within the marsh, but according to the model mud does not settle in this place initially. This might be because the roughness of the vegetation in the field, which is not in the model, stimulates mud deposition in this location (Mudd et al., 2010). Even though it is one of the higher locations on the shoal, velocities are too high for mud to settle (Fig. 11a). This suggests that vegetation established itself before mud started to accumulate in this location in the field.

Separating the mud cover of the field data in a vegetation class (with mud) and a solely mud class, vegetation abundance increases on the shoal over time, while mudflat area decreases (Fig. 9c). This is due to the elevation distribution of the shoal and how the elevation relates to velocity. The hypsometry shows that the relative trend over time is a decrease in intertidal area and an increase in high intertidal and supratidal area (Fig. 10a). The total mud cover in the field is lower than the modelled mud covered area, this is because the model calculates cover with the mud fraction in the bed instead of simple present/nonpresent rules for mud in the field data. Small percentages over the whole shoal are therefore included in the mud cover calculations, while they would not be classified as mud from aerial observations or in the field.

Fig. 11b indicates that there is a strong correlation between the maximum flow velocity over a tidal cycle and the fraction of mud that is deposited in that location. If we study the relation between water level and velocity for three individual points on the shoal (with approximately similar height but different mud fraction in the bed), we observe that the highest velocities occur just after the point starts to get flooded and during ebb flow just after maximum high water (ebb dominance, Fig. 11a). These ebb velocities exceed the critical threshold for erosion of sand, but not for mud for the most eastern point. This point indeed contains the highest mud fraction in the bed.

The main occurrence of mud in the southeast may suggest that the mud is 
also mostly supplied from the southeast; however, mud deposits from the seaward/downstream boundary dominate in the model (Fig. 9d). Approximately $85-90 \%$ of the surface mud in the model originates from the western, seaward supplied boundary (Fig. 9d). The percentage is similar to the ratio of combined sand and mud deposition discussed earlier (87\%). The ratio of mud entering the domain during flood is about $8500 \mathrm{~m}^{3}$ to $2250 \mathrm{~m}^{3}$ during ebb, so $79 \%$ of sediment entering the domain originates from the seaward boundary. Comparing these percentages, there is a small preferential settling of mud from the western boundary indicated by the different mud deposition and inflow ratios. This can be explained by Fig. 12e, that shows that mud settles just after high water slack, when a lot of water and sediment just entered the area from the western boundary. Mud entering the domain from the eastern boundary is only dominating at low tidal water levels when the flow is concentrated in the main channels.

Although the flow in the points on top of the shoal show mixed ebb-flood dominance, on average the area of Walsoorden (region of interest) is flood dominant (Fig. 12d and e). With this region of interest, we mean the entire plot window in Fig. 5 between RD coordinates 61800, 376500 and 66500, 379800, which are in meters. The peak velocities occur in the flood phase, just before maximum high water (Fig. 12e or b and d). In this period, the surface area of mud decreases by $\sim 2 \%$ compared to the maximum surface area of mud during ebb just after high water slack (Fig. 12e or a, b and d). These velocity fluctuations explain the cyclicity observed in the mud on the scale of individual tidal cycles (Fig. 12a and Fig. 9d). It should be noted that the magnitude of all cyclicity is exaggerated in Fig. 9d by the morphological acceleration factor: the response of the morphology to the hydrodynamics is faster due to the acceleration factor.

The total mud surface cover (including the vegetation class) doubles between the first two maps of the field data (Fig. 6a-b and 9c for 1996-2001). Note that there is also a long time interval between the maps that are available. After this peak the total mud cover gradually decreases. This rapid increase is also visible in the model results for the same period (Fig. 9d). After this strong increase in mud cover between 1996 and 2001 we observe a small, slow decrease. It is interesting that this trend is captured in both the field data and the model, even though the model uses a morphological acceleration factor and therefore only uses one year of water level data and disregards salt marsh vegetation. It was first hypothesised that the model first showed a yearly or seasonal trend, but since the field data shows the same large-scale trend over 20 years, it is more likely that this trend in the mud distribution is coupled to the morphological change rather than to hydrodynamics. We attribute the increase in mud cover to the increase in shoal elevation and the decrease to the narrowing of the shoal. In addition to the long-term trend, strong spring-neap cyclicity is also observed in the model (Fig. 9d), which could not be observed in the field data due to low temporal resolution (Fig. 9c).

Since the modelled morphology becomes increasingly less comparable to the real bathymetry, we also run 5 short-term models with different initial bathyme- 
tries for shorter periods, but otherwise same conditions (2001, 2004, 2008, 2012 and 2016). These models were run for 75 hydrodynamics days and 4 morphological years. They show an even better similarity of the mud deposits with the field data (Fig. 13), because the underlying morphology is more similar. These short-term runs also show an area of mud extending to the east over the middle of the shoal between 1996-2008 and disappears after (Fig. 13a-c, and Fig. 6bc). Plus, they show a better representation of mud on the north-eastern side of the shoals (Fig. 13), which is not very well represented in the long-term model (Fig. 6j-1). Conducting these short-term runs with different initial bathymetries also shows that the initial bed concentration is not very important and the model predicts mud deposits well on different initial morphologies.

\subsection{Mud in stratigraphy}

Focusing on the vertical distribution of mud, we observe that most of the subsurface consists of sand in the artificially built stratigraphy (Fig. 8a, c, e and g), the cores (Fig. 18) and the modelled stratigraphy (Fig. 8b, d, f and h). From the model is calculated that only $5.68 \%$ from the reworked sediment in the bed is mud in the area around Walsoorden. Only in the intertidal regime some mud deposition starts to occur and only at elevations near the high water level larger amounts of mud are found.

Based on the cores, we distinguish two types of mud layers: 1) Drapes, thin layers of millimetres to a maximum of a few centimetres (Martinius \& van den Berg, 2011); and 2) Mudflats, thicker layers $(>10 \mathrm{~cm})$ that occur at the surface (Fig. 18). The two different types of layers are associated with different deposition and preservation conditions.

The drapes, thinner layers of 2-20 $\mathrm{mm}$, are found at a larger range of elevations compared to the thick layers, or mudflats. Our data of the thin mud drapes is exclusively from the field data, since the layers are too detailed to be captured in the model stratigraphy. Diatom samples from these buried layers show large variations in origin (marine or brackish) and functional group (benthic or planktonic) between these layers and suggest that they are formed and preserved under different circumstances (Table. 2). On the one hand, samples 1 and 4 from core 37 and 39 show high abundances in planktonic species over benthic species (Table. 2). As we also find high foraminifera abundances and coarse grains in these samples (and in one of the samples also broken shells), it is possible that these layers were formed during storm events or exceptional high spring tide. The planktonic diatoms must have been transported to the location by strong marine influence. On the other hand, in samples 2, 3 and 5 benthic species dominate (Table 2). Benthic diatoms are unlikely to live in high dynamic and subtidal areas, so the mud in these layers was probably deposited under more calm conditions. This is certainly true for sample 2 , where we also found root remnants; however, sample 3 does not contain many diatoms in general. Combining this with the layering visible in the lacquer peels (Fig. 4), we think this mud was rapidly buried by for example bedform migration. Sample 5 is specifically interesting, since this layer consists of clay pebbles in the lacquer 
peel and is therefore a likely deposit of an older reworked clay layer that was strongly cohesive. This is supported by a high abundance of diatom fragments and the find of a (sub)-aerophilous genus that is unlikely to occur in the wet tidal environment. This genus is therefore presumably related to the environment in which the reworked clay layer was formed, originating either from a much older clay layer deposited under different environmental conditions or from a layer more landward. These deposits are probably also buried by bedform migration because there are deposited under an angle (number 5 in Fig. 4), most likely at the toe of a dune. The analysis of these mud drapes indicates that they are formed under a wide variety of conditions, however, burial probably occurred due to bedform migration or event related transport in generally more dynamic conditions.

The thicker mud layers only occur at high intertidal elevations on top of the shoal, which is observed consistently in the field data and the model. The deposits can be as thick as $1 \mathrm{~m}$ (Fig. 8b, $\mathrm{f}$ and $\mathrm{h}$ ). From the coring it was observed that the thickest layers are generally associated with marsh vegetation in the field, however, the model shows that similar thicknesses can be obtained without vegetation.

Since the thin drapes and thick mud layers are related to different processes (rapid or accidental burial versus slow accumulation), layers of thicknesses between the two aforementioned deposits (e.g. a few centimetres) are uncommon and are considered to be either temporary (seasonal or spring-neap related) or in an intermediate stage of becoming a thicker deposit. Citetherman2001 also considers the deposits in the top $10 \mathrm{~cm}$ of fine sediment in the bed (determined by ${ }^{7} \mathrm{Be}$ radionuclide tracer) temporary due to seasonal cyclicity.

The thickness of the mudflat deposits on top of the shoal is a good representation of the amount the shoal has increased in elevation. When we compare a model without mud supply to the default model with mud supply, we observe a difference in elevation. Where the model with mud accreted, the model with only sand has maintained its initial elevation (Fig. 10b and c). The increase in shoal elevation is therefore not forced by long-term changes in boundary hydrodynamics, but by mud settling on the high intertidal areas. When we transfer these insights to the field data, which also shows an accreting shoal, we can conclude that this is also likely caused by mud settling on the shoal. Other effects of mud on morphology, e.g. estuary confinement, are limited at this spatial and temporal scale.

\subsection{Sensitivity to mud parameters}

Variables that were tested for sensitivity were mud supply concentration, settling velocity, critical shear stress for mud erosion and the erosion parameter for mud. An increase (or decrease) of $20 \mathrm{mg} / \mathrm{L}$ resulted in a much larger (smaller) mud covered area. However, the main depositional locations are the same. This shows that the accumulation of mud on Walsoorden is partially limited by sediment supply and not only by flood velocity.

A decrease in settling velocity from $0.5 \mathrm{~mm} / \mathrm{s}$ to $0.1 \mathrm{~mm} / \mathrm{s}$ (as in Winterwerp 
et al., 1993) results in limited mud deposits on the shoal. The bed concentration is rarely above $40 \%$. On the other hand, increasing the settling velocity to $1 \mathrm{~mm} / \mathrm{s}$ (as in van Kessel et al., 2011), results in a larger spread of mud deposits but again similar locations, similar to increased mud supply concentrations. This indicates that with different mud parameters the same spatial distribution of mud deposits can be obtained. For example, increasing the settling velocity, but reducing the mud supply concentration could generate a similar distribution of mud as the original model, although the time scalesscale might be different.

An increase in the critical shear stress for mud erosion from 0.2 to 1 (as in van Rijn, 2018) has a very strong effect on the model results. With these settings we observe large deposits on intertidal area around mean water level, while no mud deposits accumulate at high intertidal area on top of the shoal. Another extreme result is generated by a lower erosion parameters for mud, from $1 \cdot 10^{-4}$ to $1 \cdot 10^{-7}$ (as in van Kessel et al., 2011; van Ledden \& Wang, 2001). With this lower erosion parameter most mud deposits occur in the main channel south of the shoal. Both this higher critical shear stress and lower erosion parameter show a complete mismatch with the deposits obtained from the field data and are therefore determined to be unrealistic for this location, even though some papers were found that mention these as realistic natural values.

\section{Discussion}

In the discussion we will first elaborate why mud deposits occur in certain locations and compare these locations to other systems. Second, we will discuss the cyclicity of the mud deposits that was observed in our modelling study. Third, the preservation of mud is analysed. Last, implications of this study for shoal morphology, marsh vegetation, geology and large-scale estuary development are mentioned.

\subsection{Mudflat formation on tidal bars}

To summarise our main results on mudflat formation: mud deposition mainly occurs in shallow water depths with lower velocities. In addition, high bed elevations are only inundated for a part of the tidal cycle, although the time window for mud accumulation is similar to low bed elevations (duration of high water slack). Mud on the shoal of Walsoorden is successfully trapped on the river/landward side of the shoal, because here mud deposits are shielded from the highest flow velocities that occur during flood (Fig. 11a and 12e). We expect that these findings will be comparable to other tidal bars in tide-dominated, high-energy, sand-dominant estuaries under flood-dominant conditions. Small differences might occur under a larger influence of waves that might occur closer to the mouth of the estuary or in systems with higher energy wind waves. In regards to the mud, we expect that we overestimate mud deposition by ignoring waves (de Vet et al., 2018; Maan et al., 2018), but underestimate mud deposition by ignoring biota (e.g. Weerman et al., 2010). 
A similar mud distribution was found on top of the shoal named Paap in the Ems estuary (van Straaten, 1960), which contains more mud and is less dynamic than the Western Scheldt (van Maren et al., 2016) and is therefore good to compare if our findings hold for muddier systems as well. The middle and higher parts of the shoal show higher fractions of $20-40 \%$ mud, while the sides are sandy, 2-3\% mud (Wiggers, 1960). In addition, sediment spatial samples from the Rijkswaterstaat $(2009,800 \mathrm{~m}$ resolution of the whole Ems estuary from 1989) also indicate a higher concentration of mud on the middle and higher part of the Hond-Paap shoal. It should be noted that the channel on the southwest side of the shoal is filled with mud and therefore samples towards the channel will be even muddier than on the shoal. These types of filling deposits were not observed in the Western Scheldt model, but demonstrate another mechanism of the formation of thick mud deposits in estuaries, residual tidal channel mud fills, that have not been discussed yet.

In contrast to the shoal of Walsoorden, the Hond-Paap shoal in its current state does not show the general correlation between mud and elevation. We think this is due to lateral sorting, which does not occur on Walsoorden. We hypothesise that the current shoal has grown so large after the merge of the Hond and Paap shoal (4 km width and $15 \mathrm{~km}$ long, $36 \mathrm{~km}^{2}$ ) compared to the estuary size $\left(460 \mathrm{~km}^{2}\right)$, namely to more than $50 \%$ of the estuary width (de Jonge et al., 2014), that lateral sorting started to occur on the bar similar to floodplain sedimentation, with fining away from the channel. Sand settles relatively close to the shoal edge when water flows over the shoal and mud deposits in the centre that now in 2018 also has a lower elevation than the edges of the shoal. A shallow basin has developed in the middle of the shoal. We hypothesise that lateral sorting might also be important for significantly larger shoals in the Western Scheldt, which would require modelling with several mud fractions.

\subsection{Cyclicity in mud deposits}

The temporal resolution of the model allows us to observe cyclicity in the mud deposits on the scale of individual tidal cycles and spring-neap cycles. van der Wal et al. (2010) observed seasonal cyclicity of mud deposits in the Western Scheldt by remote sensing, although no seasonal effect on the morphology was observed. The observations showed that mud coverage in summer is twice as high as in winter and mud layers become 1.5 to 2 times thicker. Herman et al. (2001) found similar results for the Molenplaat, another shoal in the Western Scheldt, a bit more seaward. They found a seasonal mud deposition thickness of $10 \mathrm{~cm}$ and a seasonal deposition area of $40 \%$ of the intertidal area and relate this to the stabilising effect by microalgae. Stabilisation effects can increase the erosion threshold of mud with a factor up to 5 (Le Hir et al., 2007). However, Le Hir et al. (2007) also states that this only influences the initiation of erosion, because after the thin biofilm is eroded the threshold for erosion will return to pure sediment erosion thresholds. This reasoning helps to understand why van der Wal et al. (2010) did not find any seasonal effects on morphological change.

Our results do not show this seasonal cyclicity. We assume this is caused by 
more frequent and higher local waves during storms in winter as opposed to mud stabilisation by biofilms (diatoms or bacteria) in spring and summer (Holland et al., 1974; Yallop et al., 1994; Herman et al., 2001), which we ignored in the model. Seasonal cycles in mud supply are also not accounted for. However, for the purposes of this study the lack of seasonality in the model is not problematic, because mud seasonality does not seem to cause seasonality in the morphology (Le Hir et al., 2007; van der Wal et al., 2010).

\subsection{Preservation of mud and geological implications}

Estuaries are often considered to be very efficient sediment traps on long timescales (10-100 ky), as they often develop in confined and deeply incised paleovalleys under sea-level rise (Demarest \& Kraft, 1987; Dalrymple et al., 1992). However, in estuaries formed under low rates of sea-level rise - such as the Western Scheldtthe preservation potential of sediments is low. This is because channel-shoal migration laterally reworks older deposits (Pierik et al., 2016), whilst relatively constant sea levels hampers the stacking of stratigraphy. While the preservation potential in the Western Scheldt is low, there is large spatial and temporal variability in preservation (Martinius \& van den Berg, 2011). Net sedimentation on top of the shoal, on the order of centimetres per year, is mostly mud according to our results. These deposits are laterally eroded by channels migrating at meters per year, predominantly depositing sand at rates of several meters a year. As only the last stage of the estuary is eventually preserved, most of the final sediment volume is deposited in an extremely small fraction of the time in which the system was active. Nevertheless, the resulting stratigraphy of the tidal bar will still reflect multiple environments on the bar. Additionally, the last stage is representative for earlier time steps, because if the estuary width is wider than the ideal exponential shape, tidal bars will always occur in these locations (Leuven et al., 2018) and most mud will occur as a top layer.

As a result of sand-mud segregation in tidal bars, the bar stratigraphy is found to be predictable and dominantly built of sand. This is in accordance with van de Lageweg et al. (2018) studying the whole estuary stratigraphy. van de Lageweg et al. (2018) also found the same mud/sand ratios in the bed of $5 \%$ compared to $5.68 \%$ in this study with deposits fining upwards. In line with the field data, it proves difficult to preserve thick mud layers $(>10 \mathrm{~cm})$ in deeper stratigraphic layers in the model. At the same time the mud covers a significant surface area of the estuary (20-40\% of the intertidal area). Even though the volume of mud might seem small when studying the estuary stratigraphy, it should be realised that this mud volume is not a good representation of the amount of mud in the estuary. A preservation bias exists; most mud deposits at the surface and is therefore more easily reworked than sand in the next high energy event. Additionally, the importance of mud at the bed surface should not be underestimated.

The field data did however show very thin mud drapes $(2-20 \mathrm{~mm})$ in deeper stratigraphic layers that were not captured in the model. These drapes were found at a wide range of depths and at locations with slightly higher energy 
conditions. In principle, mud drapes can deposit every slack water, however, the deposits can only be preserved if they are either very rapidly covered by sand before the drapes are eroded again or if they are deposited in an area shielded from flow, e.g. trough of bedforms or in pools during low tide (Martinius \& van den Berg, 2011), which is confirmed by the diatom and lacquer peels analysis. So counterintuitively, the mud drapes preferentially preserve under high energy conditions.

The overall thickness of mud in the bed is only significant in the southwestern tip of the shoal, up to $1 \mathrm{~m}$ thick (Fig. 14). The volume of mud in the substrate is also significant in places where there was a lot of deposition. Although no clear mud layers were distinguished in the cross-sections, some mud is generally mixed into the sand during low flow conditions in combination with high sedimentation rates, due to numerical diffusion in the $10 \mathrm{~cm}$ thick active layer and bed storage layers. Although no clear mud layers are formed, the total amount of mud in areas where there was significant morphological change can still be large up to a few decimetres in total when added together (Fig. 14). In reality diffusion of mud can also occur due to bioturbation, however, macrobenthos generally do not occur during rapid sedimentation.

Preservation at the shoal scale shows that over the 20 year morphological simulation $52 \%$ of the deposited sediment was reworked within the region of interest using an observational time step of one day. This number is lower than reality, because preservation and reworking calculations are dependent on the observational time step (Fig. 15. For example, within an observational time step of one day, erosion and re-deposition can occur during two tidal cycles, which might be overlooked without intermediate time steps. Shorter time intervals (0.2 min) show that the percentage reworked sediment deposit was even $58 \%$, which is closer to reality. This insight is a big step forward in understanding the classical problem of time and preservation in geological data. Unlike for rivers, preservation potential cannot be calculated from sedimentation relative to the influx of sediment, since we are dealing with tidal flow reworking the sediment on a daily basis and are using a morphological acceleration factor, creating a mismatch between the depositional volume of sediment and the actual bed level change. Vice versa, volume budgets from the geological record cannot be directly used to estimate sediment fluxes or SPM concentrations, as constant sediment recycling occurs on very short timescales.

Summarised, shoal stratigraphy of high-energy, sand-dominated estuaries reflects the spatial distribution of mud deposited over the last 10-100 years. However, mud contents or occurrences cannot be related directly to hydrodynamical processes, without being aware of the preservation mechanisms and preservation bias. In addition, the volume of mud, the ecological importance at the surface and its influence on the evolution of the system is likely to be underestimated if based solely on mud in stratigraphy. Most short term deposition and erosion cycles might also be overlooked. 


\subsection{Implications on shoal morphology and ecology}

The largest influence of mud on the morphology is increased shoal accretion. Mud increases the elevation of the shoal by depositing at high intertidal elevations where sand is hardly transported due to low flow velocities during short inundation times (as in Braat et al., 2017, 2018). These deposits fill the area between mean water level and high water level and reduce flow over the shoal. The filling and reduction of flow over the shoal increases resistance for the tide propagating through the estuary. As a consequence this can lead to local tidal prism reduction (Braat et al., 2018). However, this was not observed in the data, because it is masked by the effect of channel deepening. In addition, flow reduction over the shoal leads to a reduction in small tidal channels forming on top of the shoal. As these channels occur less often and are relatively smaller, the bar becomes more stable and is less likely to be split by cross-cutting channels. All these effects generate a positive feedback for mud deposition which is only limited when decreasing inundation times start to affect deposition.

Because tidal bar elevation increases by mud deposition, the surface area of low-dynamic muddy areas increases, which area very valuable ecological areas for benthic species, birds and fish. If the elevation of the shoal increases up to high water level, these low dynamic areas might be lost to the formation of supratidal salt marshes. Higher elevations increase opportunities for marsh. Vegetation species will be inundated less and seeds will establish easier due to lower flow velocities (Bouma et al., 2014; Cao et al., 2017). This reasoning suggests that mud deposition always occurs before vegetation establishment; however, on some locations of the shoal the mud deposits were not well reproduced, because in reality these were locations where vegetation settlement likely occurred before mud accumulation. More research is required that includes vegetation to definitively prove these hypotheses and interpretations on a small scale. On a larger scale, the modelling study of Lokhorst et al. (2018) supports that vegetation follows mud accumulation and that the vegetation enhances mud settling.

Understanding the spatial and vertical distribution of mud layers will improve future modelling studies of estuaries. This study gives a methodology to account for mud and a range of parameters that can be used to obtain realistic results that are verified with field data. Especially for the Western Scheldt and estuaries similar to the Western Scheldt, it is shown that although the total volume of mud in the bed is very small ( $5 \%$ of the sediment), it has significant effects on shoal elevation, ecological areas and the sediment balance as the surface cover is much higher than $5 \%$ mud percentage.\% The successful modelling of these mud deposits will also allow assessment of possible effects of changes in tidal range, freshwater influx from the river and from precipitation and sea level rise under increasing climate change and human interference. Our detailed sedimentological data on the occurrence and preservation of mud is important for reservoir modelling, permeability of the substrate and ecosystem development in high energy estuaries. We provide a better understanding of the processes that control deposition and preservation, which can be especially helpful for 
geological and ecological studies.

\section{Conclusions}

The aim of this study was to better understand; (1) the location and the conditions of mud deposition; (2) how mud layers are preserved in the stratigraphy; and (3) what the implications are for the morphodynamics of the estuary. All to better understand how formative conditions of mudflats effect the preservation potential and estuary morphology. We showed that the locations of mud deposits are mainly determined by a combination of elevation and flow pattern and velocity. High-intertidal areas that are shielded from high (flood) velocities during high water form optimal conditions in high energy systems for mud deposition. Most mud on the shoal of Walsoorden therefore deposited at high intertidal elevations on the south-eastern side of the shoal and originated from the seaward boundary.

Only limited mud is preserved in deeper stratigraphic layers. We distinguished two types of mud deposits that are associated with different locations and processes: 1) Mudflats, thick (>10 cm) mud deposits on top of the shoal that are formed by slow accumulation over time; and 2) mud-drapes, thin (millimetres to centimetres) thick deposits that form and preserve more rapidly at a wider range of elevations. The thin layers have negligible influence on the morphology while the thick layers increase shoal elevation. Layers of intermediate thicknesses are considered temporary and mostly seasonal.

An increase in shoal elevation by mud increases the amount of low-dynamic muddy areas that are valuable for ecology, is likely to stimulate salt marsh growth on the shoal raising the shoal to supratidal levels, reduces cross-cutting by small tidal channels and reduces the tidal prism. Stratigraphic mud contents or occurrences cannot be related directly to hydrodynamical processes, without being aware of the preservation mechanisms and preservation bias. While only a small percentage of the stratigraphy consists of mud (here 5\%), the mud cover at the surface is much higher (here $20-40 \%$ of the intertidal area) and effects of mud on ecology and evolution of the system should therefore not be underestimated in geological. 


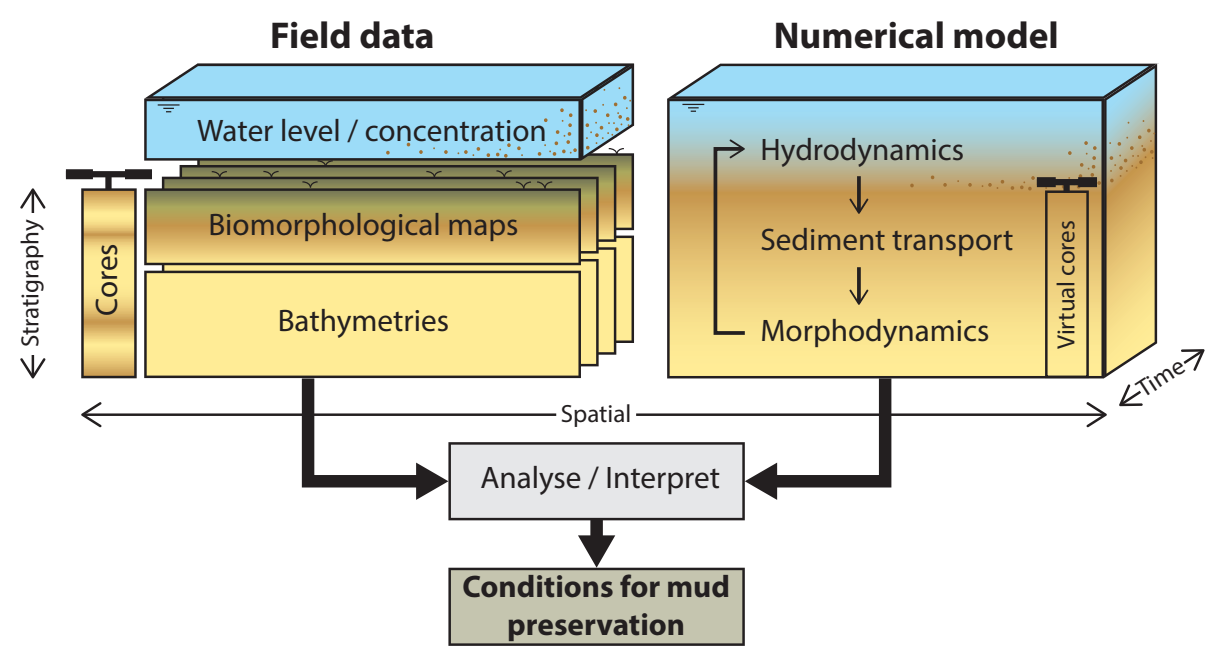

Figure 1: Conceptual figure of the methodology, which combines a study on field data and a numerical morphological model including mud and stratigraphy.

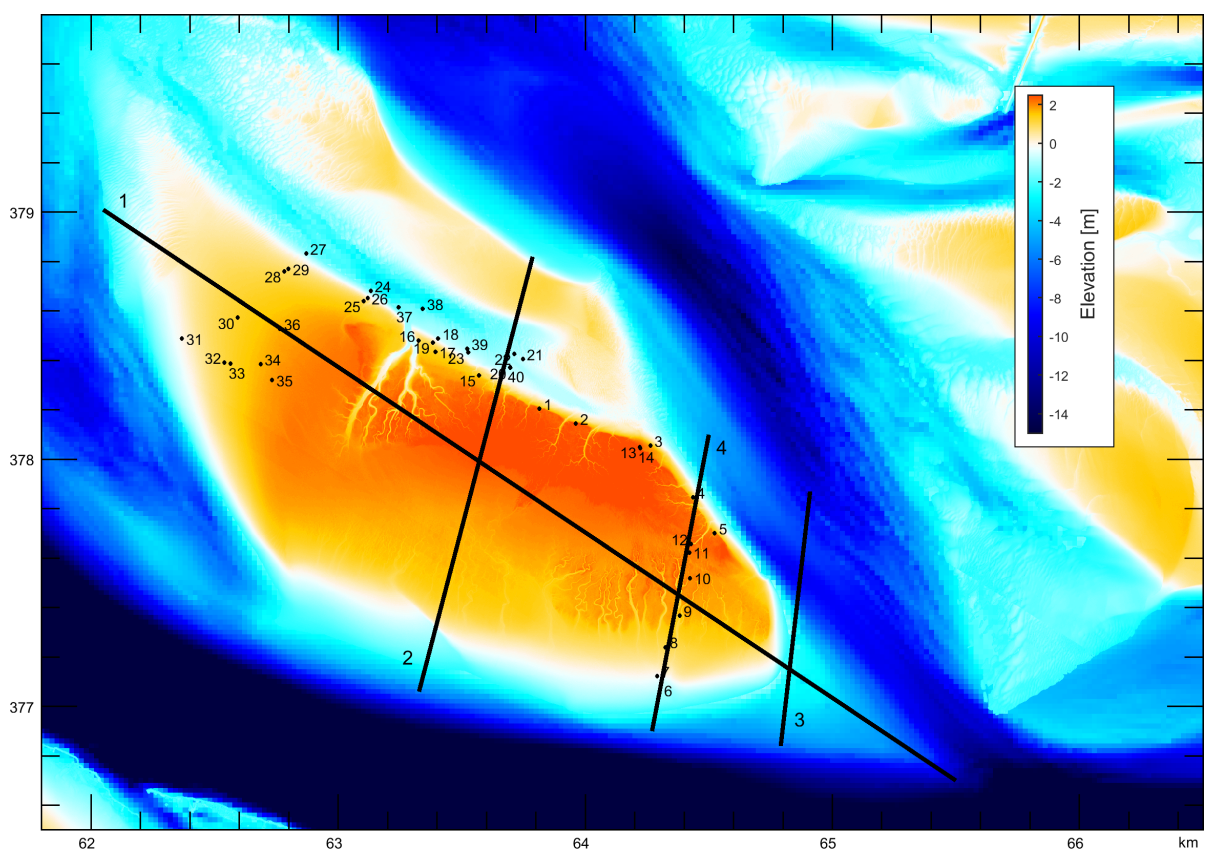

Figure 2: Numbered positions of cores on the bathymetry (vaklodingen $+\mathrm{Li}$ DAR) of 2016. Lines indicate transects that are used in later figures. Horizontal and vertical axes are RD-coordinates in kilometres. 

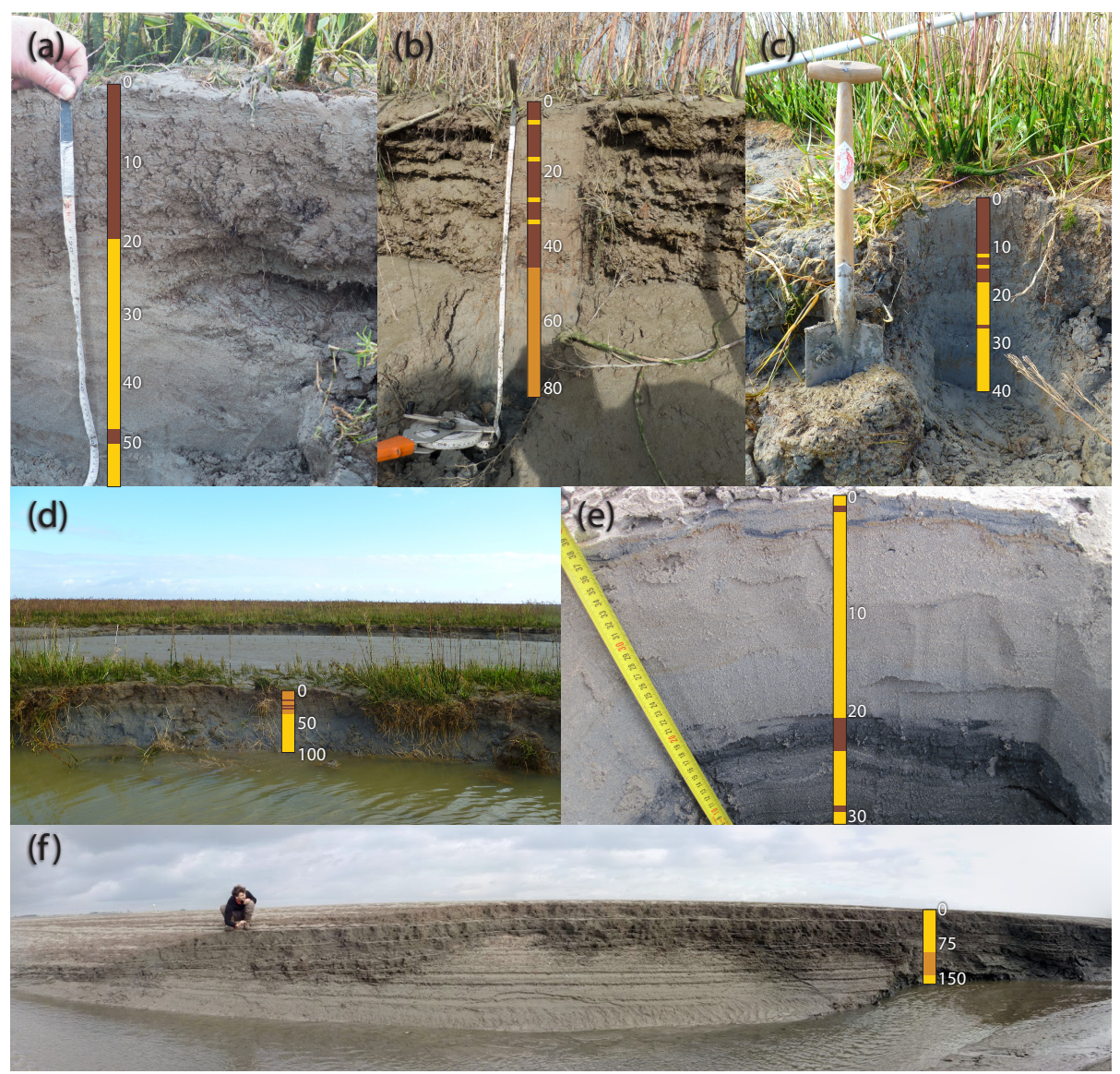

Figure 3: Field site pictures of Walsoorden. a-c) Marsh edges; d) bluff besides tidal channel; e) dug section in high dynamic area; and f) channel wall of biggest tidal channel on the shoal. Subsequent photos are at core locations 1, 12, 5, 9, 25 and 16 on Fig. 2, core sediments are shown in front of the photographs. 


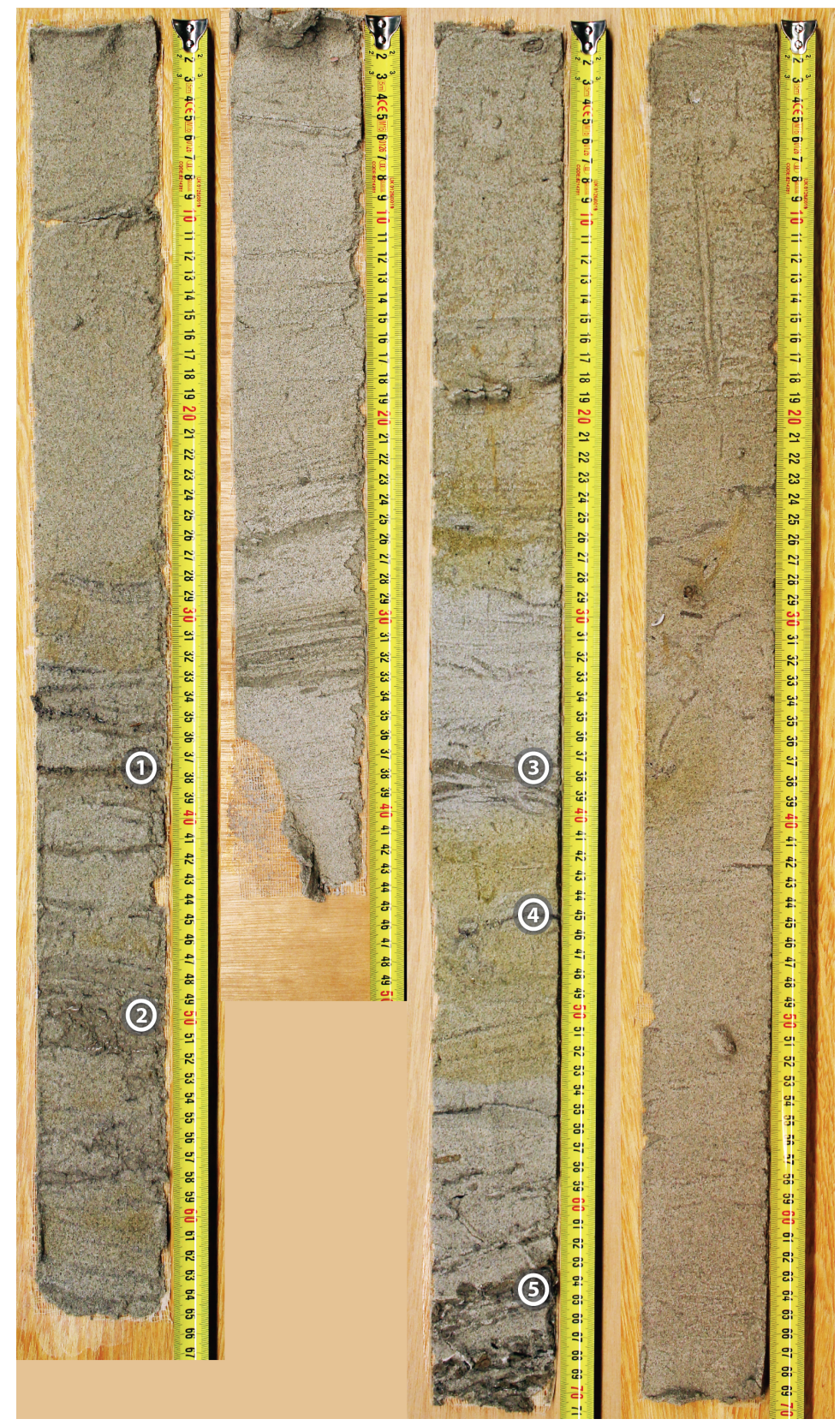

Figure 4: Lacquer peels from flood channel Walsoorden. Core locations 37, 38, 39 and 40 on Fig. 2. Darker coloured layers are mud layers. Numbers indicate diatom sample locations. 
Table 1: Model settings

\begin{tabular}{|c|c|c|c|}
\hline Sand & & & \\
\hline Grain size & $2 \mathrm{e}-4$ & $\mathrm{~m}$ & McLaren (1994) \\
\hline Dry bed density & 1600 & $\mathrm{~kg} / \mathrm{m}^{3}$ & \\
\hline Mud & & & as used in \\
\hline Settling velocity & $5 \mathrm{e}-4$ & $\mathrm{~m} / \mathrm{s}$ & $\begin{array}{l}\text { van Ledden \& } \\
\text { Wang (2001); } \\
\text { van Ledden, } \\
\text { Wang, et al. } \\
\text { (2004); Cancino } \\
\text { \& Neves (1999) }\end{array}$ \\
\hline Critical bed shear stress for erosion & 0.2 & $\mathrm{~N} / \mathrm{m}^{2}$ & $\begin{array}{l}\text { Winterwerp } \\
\text { et al. (1993); } \\
\text { Braat et al. } \\
(2017)\end{array}$ \\
\hline Critical bed shear stress for deposition & 1000 & $\mathrm{~N} / \mathrm{m}^{2}$ & $\begin{array}{l}\text { Sanford \& } \\
\text { Halka (1993); } \\
\text { van Kessel et } \\
\text { al. (2011); Dam } \\
\& \text { Bliek (2013); } \\
\text { Braat et al. } \\
(2017)\end{array}$ \\
\hline Erosion parameter & $1 \mathrm{e} 4$ & $\mathrm{~kg} / \mathrm{m}^{2} / \mathrm{s}$ & $\begin{array}{l}\text { Dam \& Bliek } \\
\text { (2011); van Led- } \\
\text { den, Wang, et } \\
\text { al. (2004); Braat } \\
\text { et al. (2017) }\end{array}$ \\
\hline Dry bed density & 1000 & $\mathrm{~kg} / \mathrm{m}^{3}$ & \\
\hline Boundary concentration & 40 & $\mathrm{mg} / \mathrm{l}$ & Fig. 16 \\
\hline \multicolumn{4}{|l|}{ Other settings } \\
\hline Active layer thickness & $5 \mathrm{e}-2$ & $\mathrm{~m}$ & \\
\hline Max storage layer thickness & $5 \mathrm{e}-2$ & $\mathrm{~m}$ & \\
\hline Morphological acceleration factor & 20 & - & \\
\hline
\end{tabular}




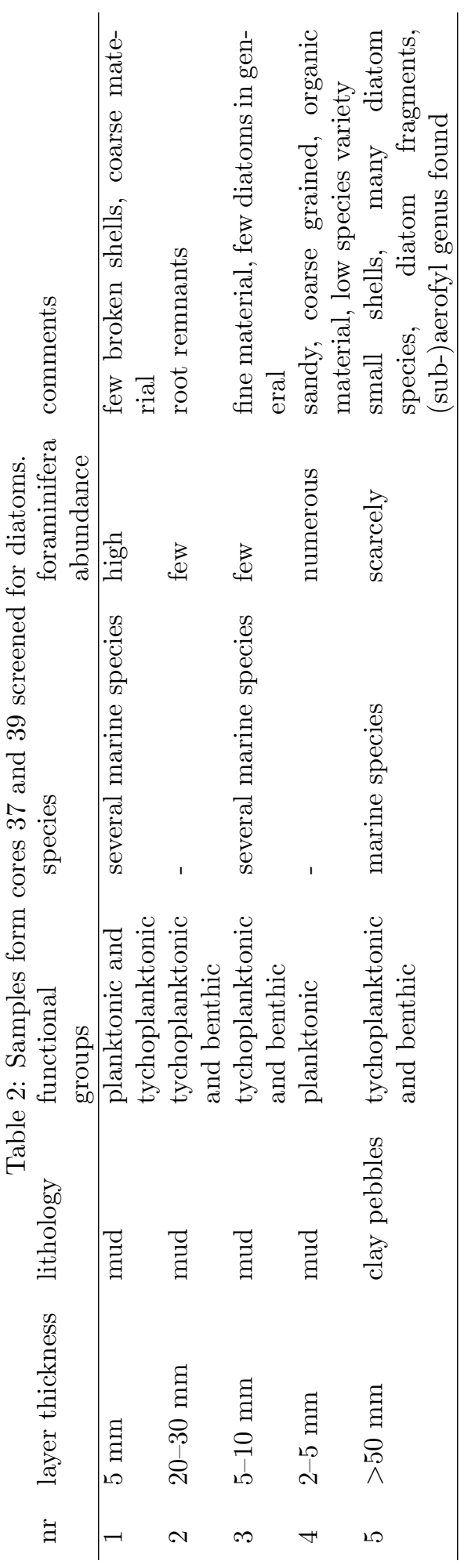




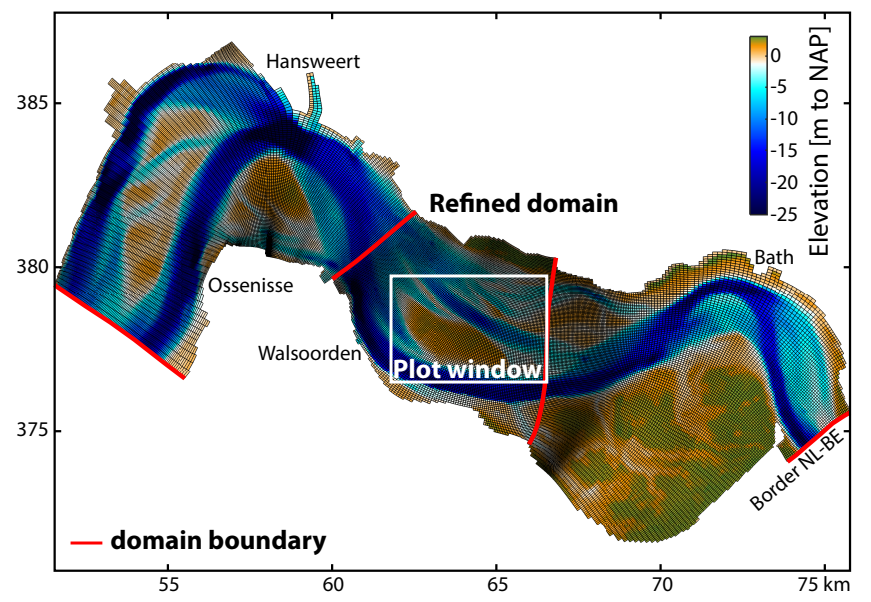

Figure 5: Model grid of the two domains with boundaries indicated in red and initial bathymetry of 1996. The inner domain is refined in the main flow direction, along estuary (not transverse). The indicated plot window is the area used in all calculations in the paper. Horizontal and vertical axes are RD-coordinates in kilometres. 

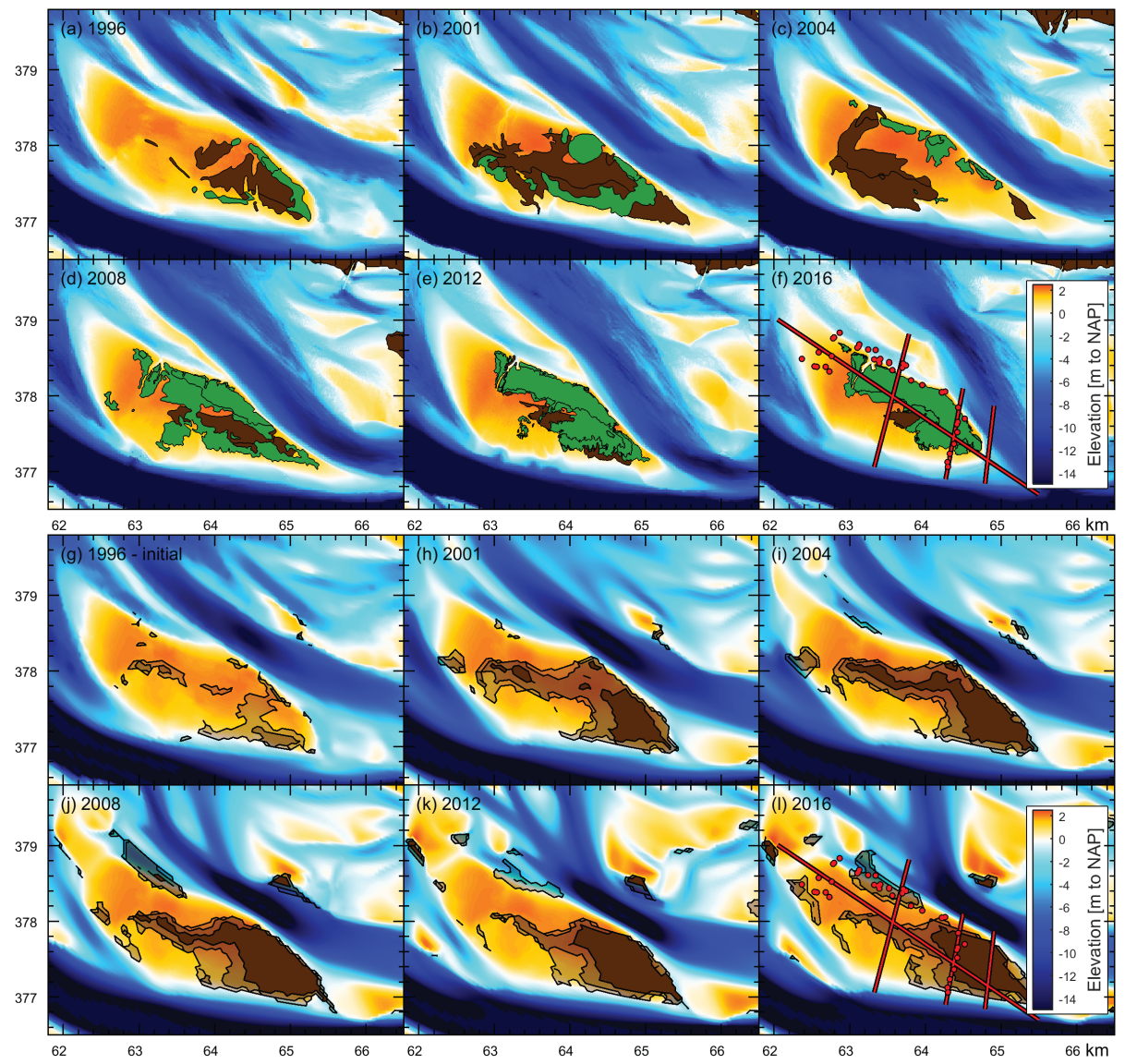

Figure 6: Morphology of Walsoorden with mud on top of the bed comparing field data and modelling results. (a-f) Field data bathymetry with vegetation and mud-rich classes for the years that biomorphological maps are available. (g1) Modelled bathymetry of Walsoorden with mud classes (fraction $>40 \%,>50 \%$ and $>90 \%$ ) for the top layer of the bed. (f,l) Red dots indicate field locations and red lines indicated the transects (Fig. 2). Horizontal and vertical axes are RD-coordinates in kilometres. 

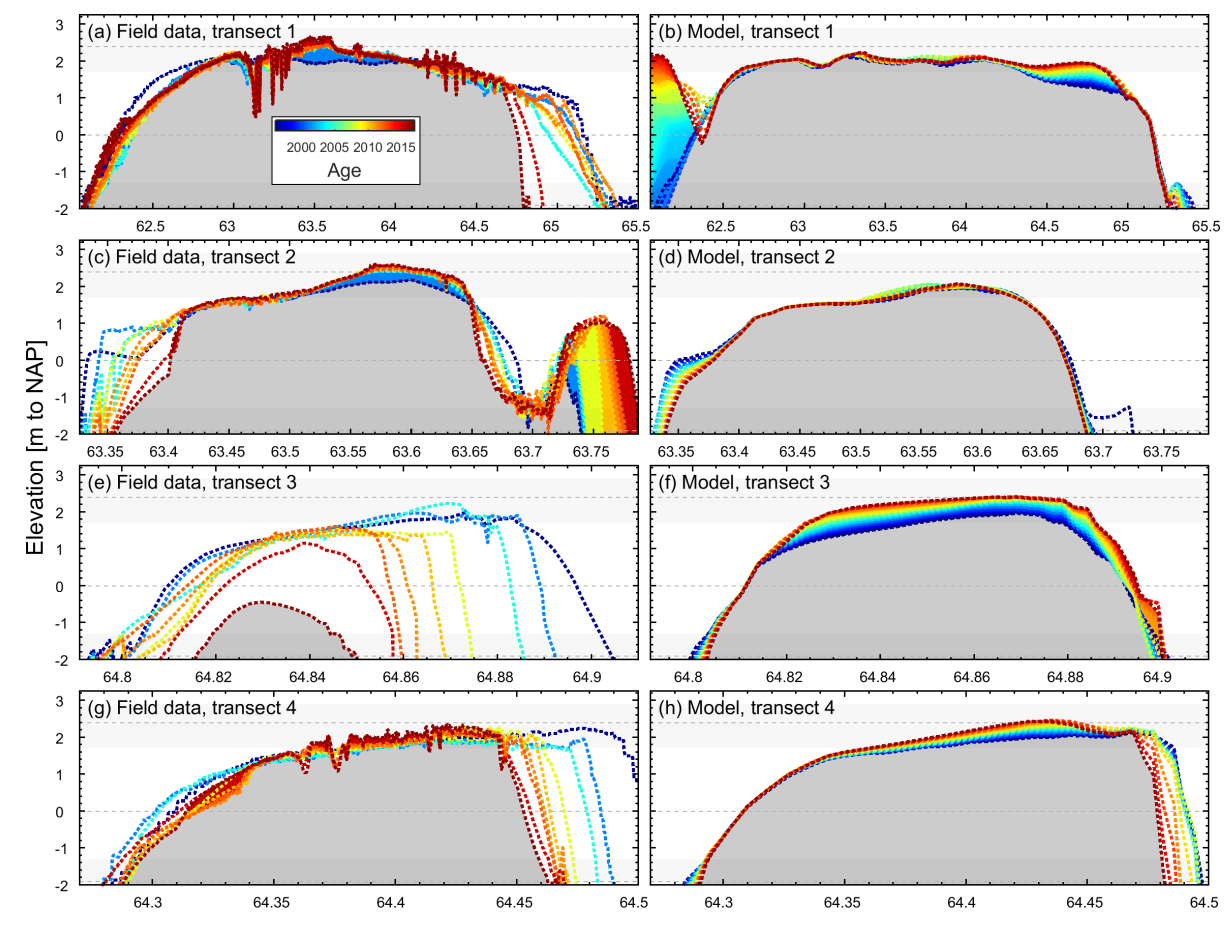

Figure 7: Stratigraphic age: Left column (a,c,e,g), four transects based on a composite of bed profiles (LiDAR + DGPS) of nine years. Right column $(\mathrm{b}, \mathrm{d}, \mathrm{f}, \mathrm{h})$, same transects from the morphodynamic model. Colours indicate before which date the sediment was deposited going back to 1996. Grey areas are deposits of unknown age deposited before 1996. Dotted lines are the bed elevations in that year. Dashed grey lines are mean low, mean and mean high water level. Range of high and low water level is indicated by a light grey overlay as well. Horizontal axis shows west-east RD-coordinates in kilometres. 


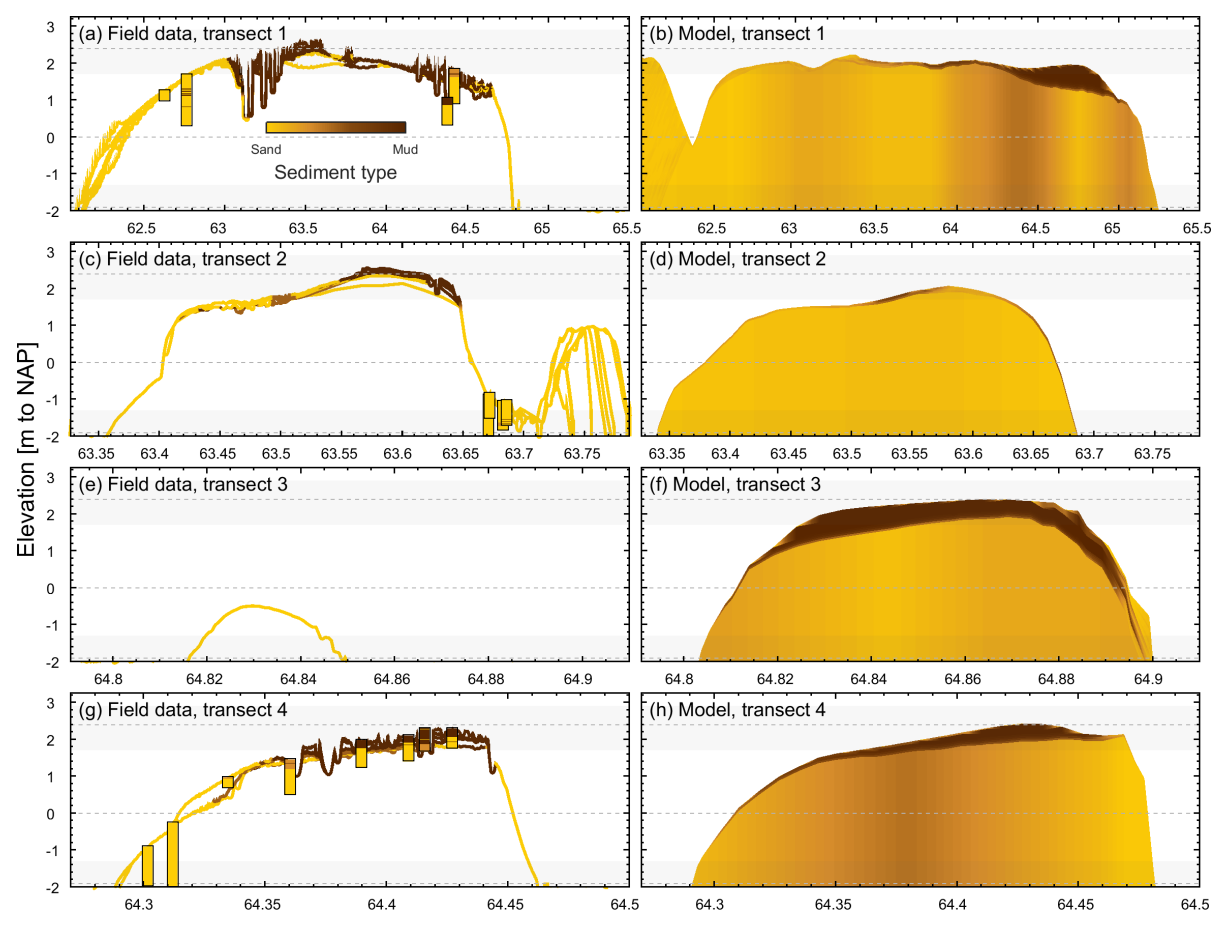

Figure 8: Lithology: Left column (a,c,e,g), four transects based on a composite of bed profiles (LiDAR + DGPS) and biomorphological maps of nine years. Right column (b,d,f,h), modelled lithology of the same transects. Colours indicate sedimentary stratigraphy: dark colours are mud and light colours are sand. Field cores are plotted in front of the field cross-sections. Dotted lines are the bed elevations in that year. Dashed grey lines are mean low, mean and mean high water level. Range of high and low water level is indicated by a light grey overlay as well. Horizontal axis shows west-east RD-coordinates in kilometres. 

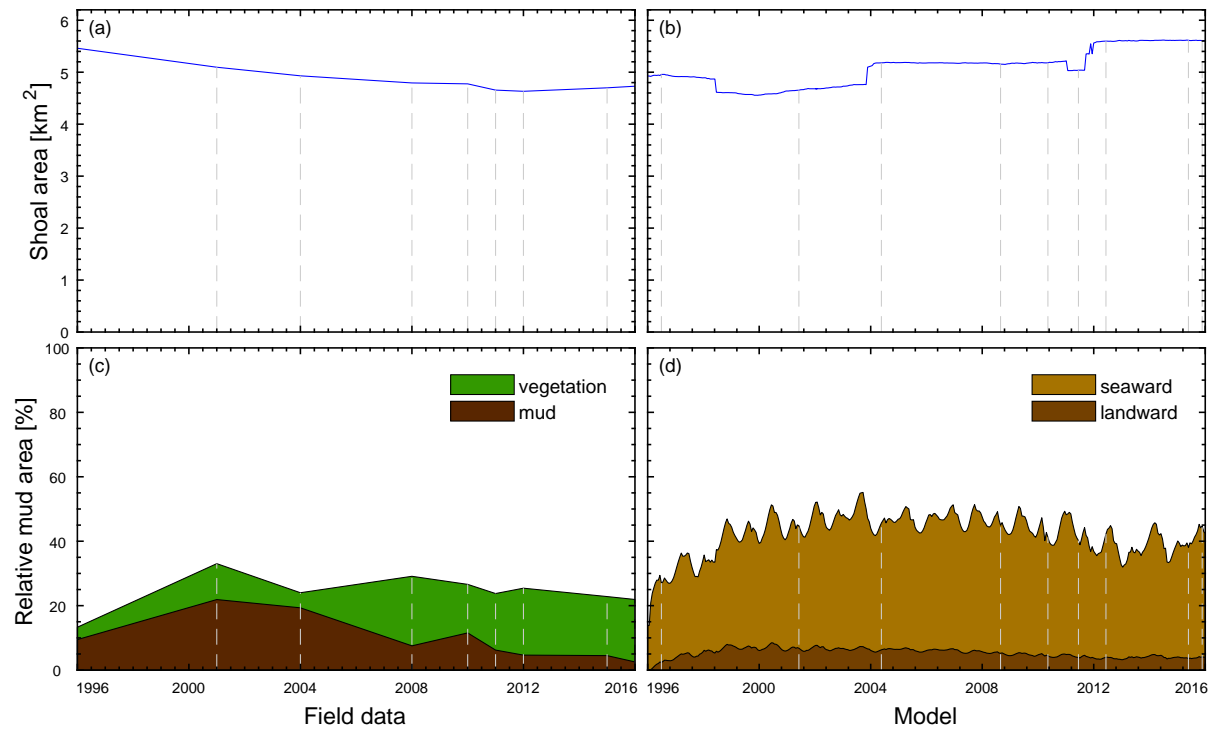

Figure 9: (a-b) Shoal area above maximum low water level $(-2.4 \mathrm{~m})$ and $(\mathrm{c}-\mathrm{d})$ relative surface mud cover based on fraction in the top of the bed on the shoal over time for the field data (a,c) and the model data (b,d). Dashed grey lines correspond to the dates of the biomorphological maps. Note that at least a large fraction of the vegetation grows on the mud. Discontinuities in (b) are cause by interpretation thresholds by analysing areas that do (not) belong to the shoal.

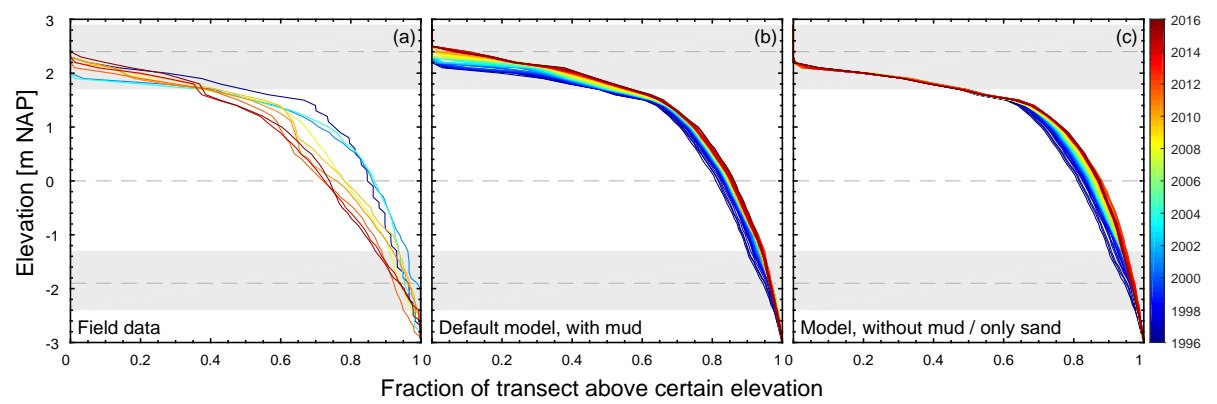

Figure 10: Cumulative, relative elevation distribution between -3 m NAP and the top of the shoal, i.e. hypsometry, for (a) field data, (b) the default model with mud and (c) a model without mud but otherwise same conditions. All hypsometries are based on transect 4 (Fig. 2). Dashed grey lines are mean low, mean and mean high water level. Range of high and low water level is indicated by a light grey overlay as well. 

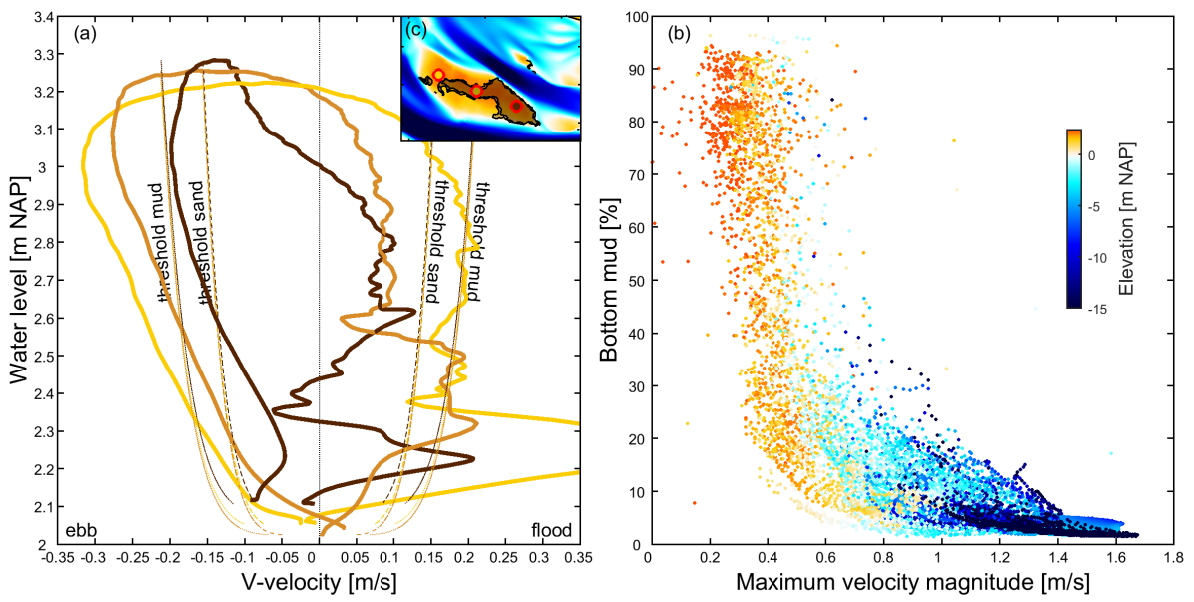

Figure 11: Relations between velocity and mud fraction in the bed. (a) Velocity plotted against water level of one tidal cycle in 2001 (close to time of the biomorphological map) for three points on the shoal indicated in (c). These points are of similar elevation between 2.02 and $2.08 \mathrm{~m}$ and have low, average and high concentrations of mud in the bed. Dotted lines indicate the critical threshold for erosion of sand and mud. (b) Maximum velocity magnitude over a tidal cycle against minimum fraction of mud in the bed over a tidal cycle in 2001 for the whole area plotted in subplot (c). 

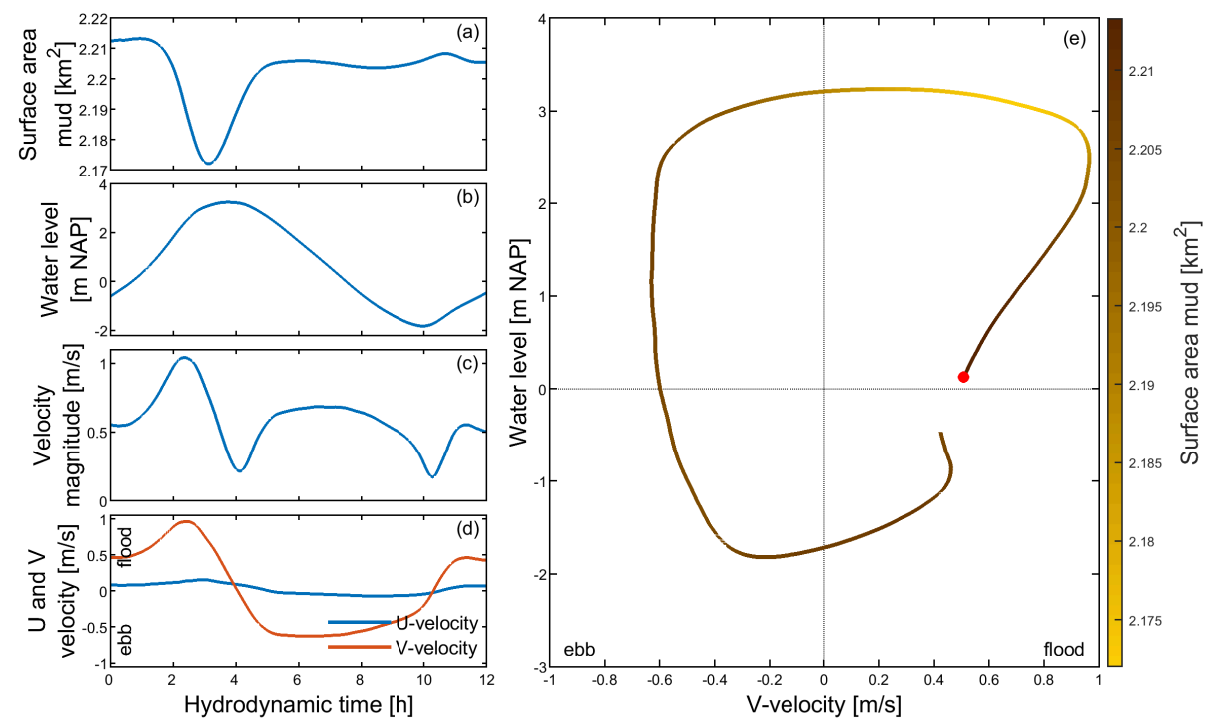

Figure 12: Relations between spatially averaged velocity, spatially averaged water level and mud fraction in the bed for the plotting window between RD coordinates 61800,376500 and 66500,379800 . (a) Total amount of mud at the surface, (b) water level, (c) velocity magnitude and (d) U and V velocities over one tidal cycle in 2001. U-velocity is the cross-channel velocity and V the along-channel velocity based on the grid orientation. (e) Picture summarising the relation between velocity, water level and surface mud area over one tidal cycle. The red dot indicates the start of the tidal cycle. Note that v-velocity is plotted on the $\mathrm{x}$-axes, because it is the dominant flow direction as is shown in (d). 


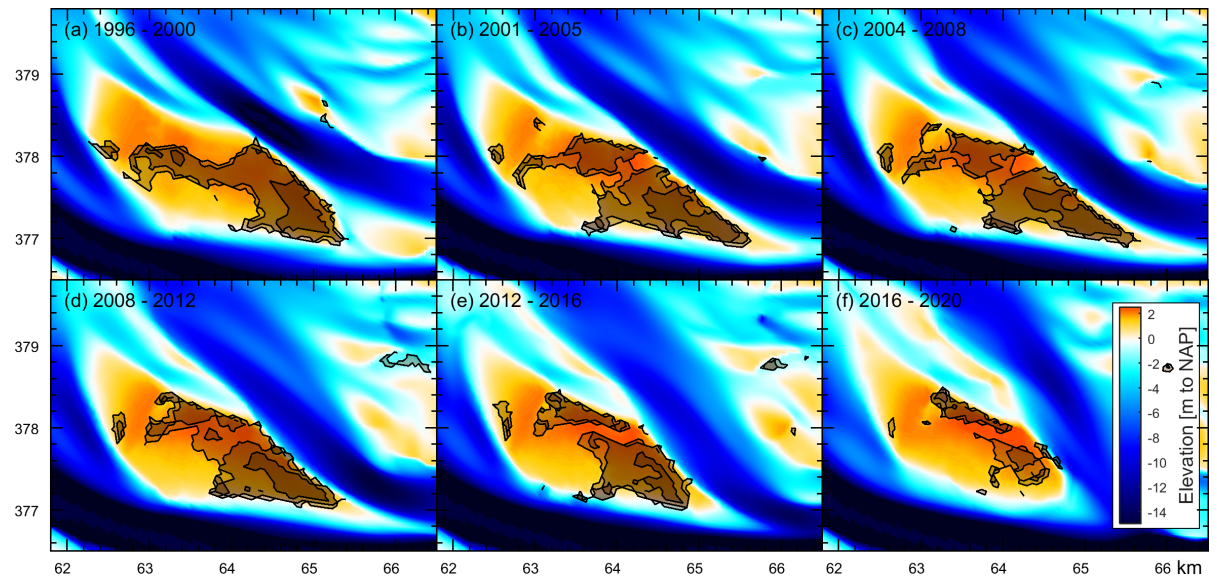

Figure 13: Six models with different initial bathymetries run for 4 year of morphodynamics and 75 days of hydrodynamics. Modelled bathymetry of Walsoorden with mud at the surface (fraction $>40 \%,>50 \%,>90 \%$ ) for the top layer of the bed. Horizontal and vertical axes are RD-coordinates in kilometres.

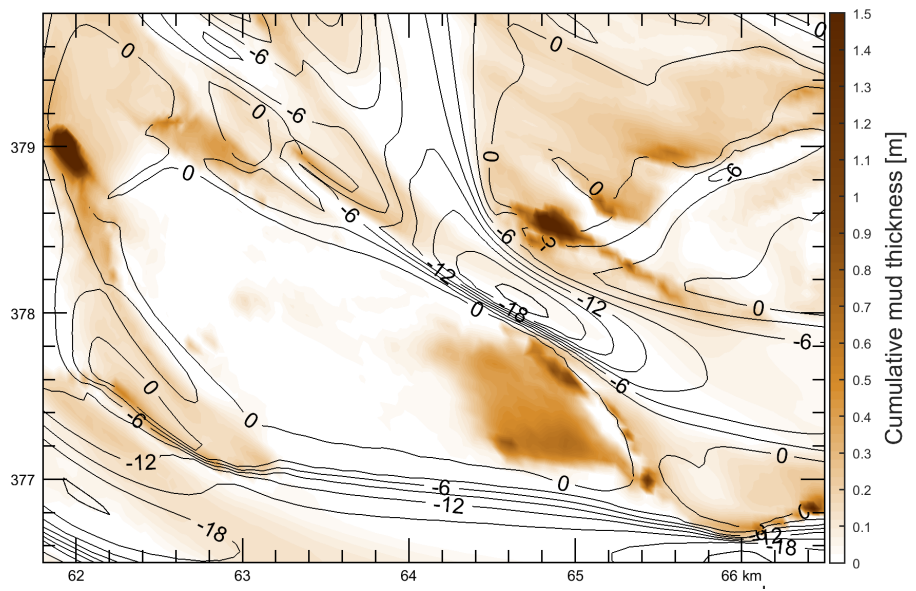

Figure 14: Modelled cumulative mud thickness per cell within the region of interest. Contour lines indicate the elevation of the shoal in 2016. Horizontal and vertical axes are RD-coordinates in kilometres. 

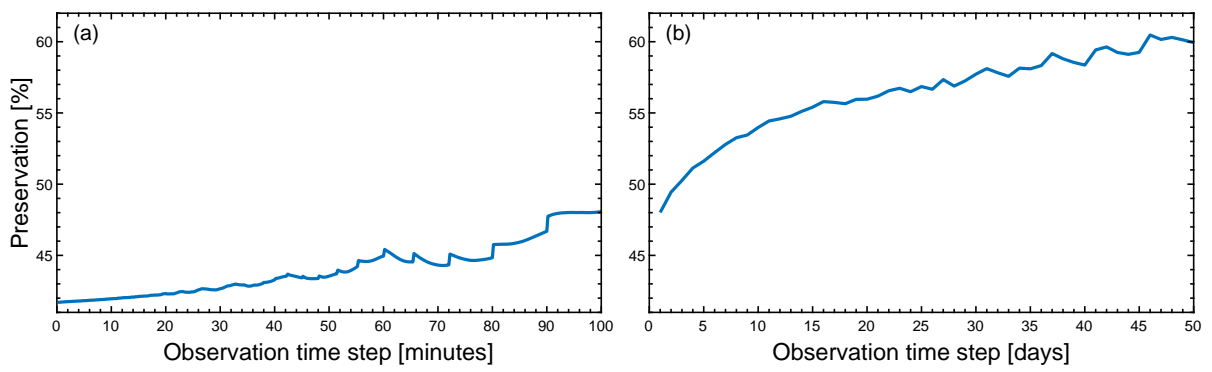

Figure 15: Percentage of apparent preservation depended on observation interval. Preservation percentage is calculated by comparing the cumulative sedimentation over all time steps to the sedimentation between the first and final time step. (a) Preservation of the long-term model of twenty years, and (b) preservation of the model of one tidal cycle. 


\section{A Appendix Figures}

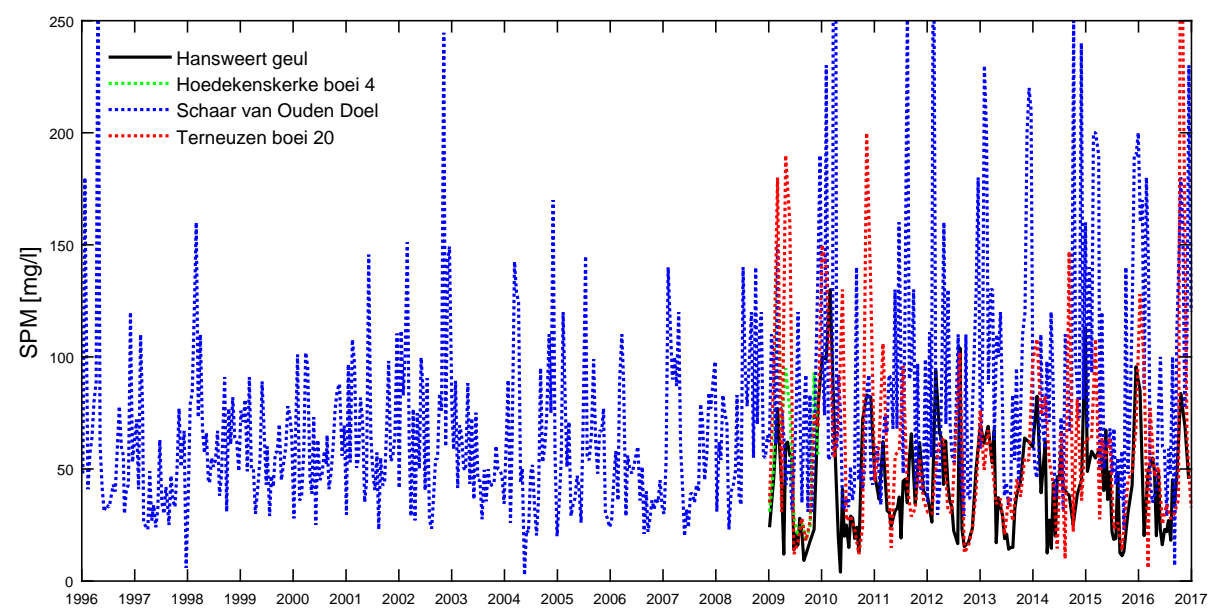

Figure 16: Measured suspended particulate matter (SPM) concentrations for four stations within the model domain. Collection of all data available between 1996 and 2017. Median concentration for the four stations are 38.8, 51.0, 60.0 and $49.3 \mathrm{mg} / \mathrm{L}$. Hansweert $(38.8 \mathrm{mg} / \mathrm{l})$ is the nearest station to the shoal of Walsoorden. 


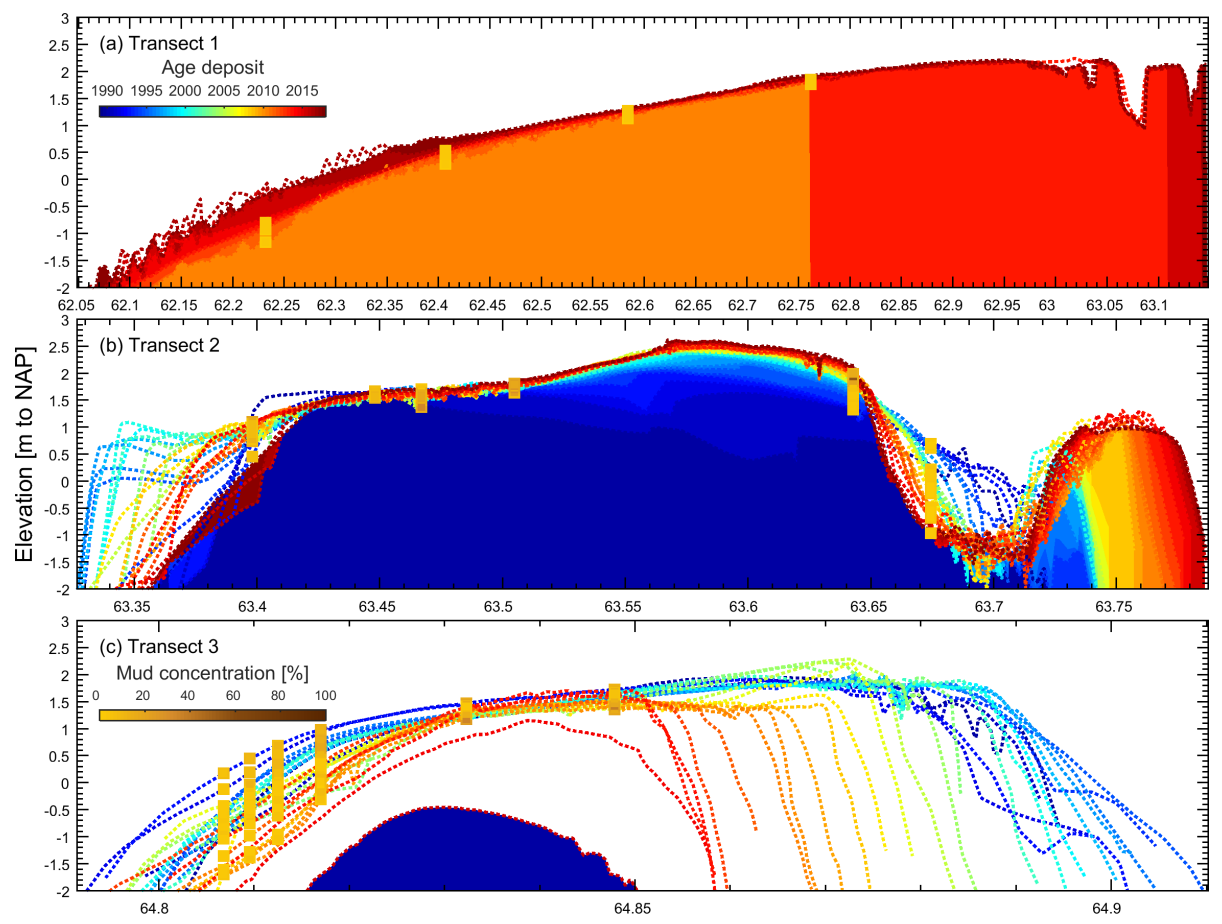

Figure 17: Stratigraphic age of three transects indicated on Fig. 2. Colour indicates before which date the sediment was deposited going back to January 1990 for plot (b) and (c) and September 2010 for (a). Since not all measured transects have the same length in (a), this results in some unavoidable artefacts in the base of the plot. Dotted lines are the bed elevations in that year. Coloured squares are mud concentration measurements in the bed for the top 10 (big squares) and $2 \mathrm{~cm}$ (small squares plotted on top) for the same years as the elevation measurements. Horizontal axis shows west-east RD-coordinates in kilometres. 
Table 3: Conditions at the times photos were gathered for the biogeomorphological maps. Low and high water levels during this day were obtained from the station at Hansweert (Rijkswaterstaat, NL).

\begin{tabular}{lll} 
date & low wl $[\mathrm{m}]$ & high wl $[\mathrm{m}]$ \\
\hline $1996-06-06$ or 17 & -2.34 & 2.70 \\
$2001-05-24$ & -2.46 & 2.65 \\
$2004-06-09$ & -1.84 & 2.45 \\
$2008-09-18$ & -2.37 & 2.66 \\
$2010-05-19$ & -2.16 & 2.44 \\
$2011-07-05$ & -2.23 & 2.67 \\
$2012-06-24$ or 25 & -2.42 & 2.81 \\
$2015-06-17$ & -2.43 & 2.62 \\
$2016-08-23$ or 24 & -2.10 & 2.83
\end{tabular}




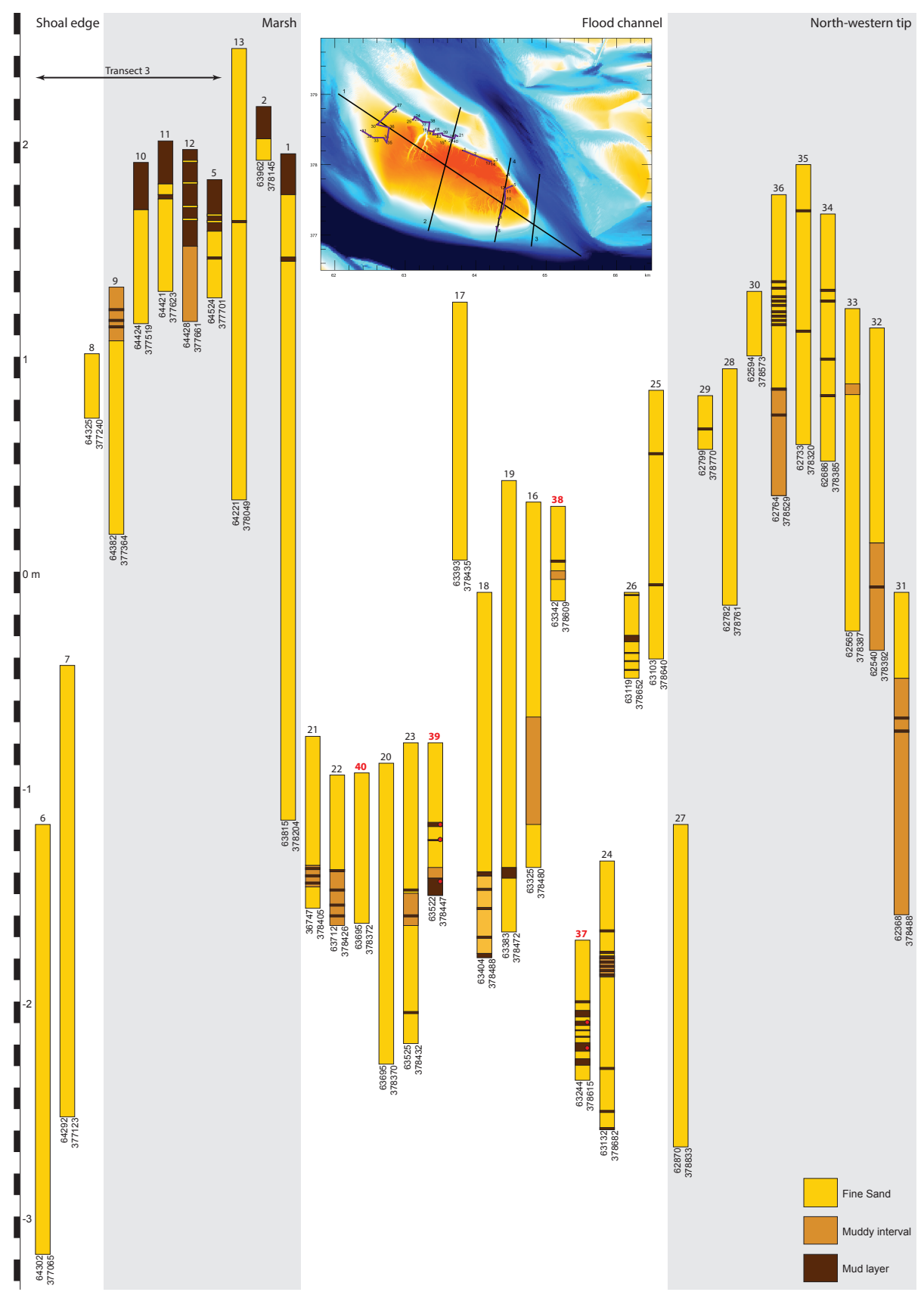

Figure 18: Core descriptions of Walsoorden Fieldwork of 23 October 2017. Cores are numbered and positions are indicated in Fig. 2. On some occasions we found sand with a little clay mixed in the layer or a set of millimetre thin clay layers in a sand dominated stretch, we defined these as muddy intervals. 
This research was funded by the Domain of Applied and Engineering Sciences TTW (grant Vici 016.140.316/13710 to MK) of the Netherlands Organisation for Scientific Research (NWO) and is part of the PhD project of LB. We would like to thank Rijkswaterstaat for the sharing of data and their support during the fieldwork. In particular Marco Schrijver, Gert-Jan Liek, Robert Jentink and Edwin Paree. We would also like to thank Marcio Boechat Albernaz, Christian Schwarz, Anne Baar and Jasper Leuven for helpful discussions. Diatom screening of the samples was conducted by Koeman and Bijkerk. The manuscript was greatly improved by comments of Bram van Prooijen, Ton Hoitink and two anonymous reviewers.

Authors contributed approximately in the following proportions to fieldwork and preparation, modelling and setup, analysis and conclusions and manuscript preparation: $\operatorname{LB}(15,80,65,70 \%), \operatorname{WvD}(10,10,5,5 \%), \operatorname{HJP}(25,0,10,10 \%)$, $\operatorname{WvdL}(25,0,0,5 \%), \operatorname{MB}(10,5,5,5 \%), \operatorname{FWC}(0,0,5,0 \%)$ and $\operatorname{MK}(15,5,10$, $5 \%)$.

Data availability: The Delft3D model software is open source and the code is available from the Deltares website (https://oss.deltares.nl/web/delft3d). Input files for the long-term default model are included in a supplementary zip file. All field data from Rijkswaterstaat is publicly available from a variety of web portals or via the service desk (https://www.rijkswaterstaat.nl/zakelijk/opendata). The raw field core descriptions from Walsoorden are also included in the supplementary information as an excel file.

\section{References}

Allen, J. R. L. (1990). The severn estuary in southwest britain: its retreat under marine transgression, and fine-sediment regime. Sedimentary Geology, 66 (1-2), 13-28. doi: 10.1016/0037-0738(90)90003-C

Bouma, T. J., van Belzen, J., Balke, T., Zhu, Z., Airoldi, L., Blight, A. J., ... Herman, P. M. J. (2014). Identifying knowledge gaps hampering application of intertidal habitats in coastal protection: Opportunities \& steps to take. Coastal Engineering, 87, 147-157. doi: 10.1016/j.coastaleng.2013.11.014

Braat, L., Leuven, J. R. F. W., Lokhorst, I. R., , \& Kleinhans, M. G. (2018). Effects of estuarine mudflat formation on tidal prism and large-scale morphology in experiments. Earth Surface Processes and Landforms, 44(2), 417-432. doi: $10.1002 /$ esp.4504

Braat, L., van Kessel, T., Leuven, J. R. F. W., \& Kleinhans, M. G. (2017). Effects of mud supply on large-scale estuary morphology and development over centuries to millennia. Earth Surface Dynamics, 5(4), 617-652. doi: 10.5194/esurf-5-617-2017

Cancino, L., \& Neves, R. (1999). Hydrodynamic and sediment suspension modelling in estuarine systems: Part ii: Application to the western scheldt 
and gironde estuaries. Journal of Marine Systems, 22(2-3), 117-131. doi: 10.1016/S0924-7963(99)00036-6

Cao, H., Zhu, Z., Balke, T., Zhang, L., \& Bouma, T. J. (2017). Effects of sediment disturbance regimes on spartina seedling establishment: Implications for salt marsh creation and restoration. Limnology and Oceanography, 63(2), 647-659. doi: 10.1002/lno.10657

Chen, M. S., Wartel, S., van Eck, B., \& van Maldegem, D. (2005). Suspended matter in the scheldt estuary. Hydrobiologia, 540(1-3), 79-104. doi: 10.1007/ s10750-004-7122-y

Dalrymple, R. W., \& Choi, K. (2007). Morphologic and facies trends through the fluvial-marine transition in tide-dominated depositional systems: a schematic framework for environmental and sequence-stratigraphic interpretation. Earth-Science Reviews, 81(3), 135-174. doi: 10.1016/j.earscirev .2006 .10 .002

Dalrymple, R. W., Makino, Y., \& Zaitlin, B. A. (1991). Temporal and spatial patterns of rhythmite deposition on mud flats in the macrotidal cobequid bay-salmon river estuary, bay of fundy, canada. In D. Smith, G. Reinson, B. Zaitlin, \& R. R. (Eds.), Clastic tidal sedimentolog (pp. 137-160). CSPG Special Publications.

Dalrymple, R. W., Zaitlin, B. A., \& Boyd, R. (1992). Estuarine facies models: conceptual basis and stratigraphic implications: perspective. Journal of Sedimentary Research, 62(6), 1130-1146. doi: 10.1306/D4267A69-2B26-11D7 $-8648000102 \mathrm{C} 1865 \mathrm{D}$

Dam, G. (2013). Harde lagen westerschelde - instandhouding vaarpassen schelde milieuvergunningen terugstorten baggerspecie (Achtergrondrapport A-28 No. I/RA/11387/12.107/GVH). International Marine \& Dredging Consultants, Deltares, Svasek Hydraulics and ARCADIS: Vlaams nederlandse Schelde commissie.

Dam, G., \& Bliek, A. J. (2011). Hindcasting the morphological impact of 2 dams in the western scheldt estuary using a sand-mud model. In River, coastal and estuarine morphodynamics: Rcem2011.

Dam, G., \& Bliek, A. J. (2013). Using a sand-mud model to hindcast the morphology near waarde, the netherlands. In Proceedings of the institution of civil engineers-maritime engineering (Vol. 166, pp. 63-75). doi: 10.1680/ maen.2011.43

Dam, G., \& Bliek, B. (2017). Lange-termijn sedimentbalans van de westerschelde (Rapport No. 1778/U16516/D/GD). Rotterdam, The Netherlands: Svasek Hydraulics. 
Davis Jr, R. A. (2012). Tidal signatures and their preservation potential in stratigraphic sequences. In R. A. Davis Jr \& R. W. Dalrymple (Eds.), Principles of tidal sedimentology (pp. 35-55). Springer Science \& Business Media. doi: 10.1007/978-94-007-0123-6_3

de Boer, P. L., Oost, A. P., \& Visser, M. J. (1989). The diurnal inequality of the tide as a parameter for recognizing tidal influences. Journal of Sedimentary Petrology, 59(6), 912-921. doi: 10.1306/212F90B1-2B24-11D7 $-8648000102 \mathrm{C} 1865 \mathrm{D}$

de Haas, T., Pierik, H. J., van der Spek, A. J. F., Cohen, K. M., van Maanen, B., \& Kleinhans, M. G. (2018). Holocene evolution of tidal systems in the netherlands: Effects of rivers, coastal boundary conditions, eco-engineering species, inherited relief and human interference. Earth-Science Reviews, 177, 139-163. doi: 10.1016/j.earscirev.2017.10.006

de Jonge, V. N., Schuttelaars, H. M., van Beusekom, J. E. E., Talke, S. A., \& de Swart, H. E. (2014). The influence of channel deepening on estuarine turbidity levels and dynamics, as exemplified by the ems estuary. Estuarine, Coastal and Shelf Science, 139, 46-59. doi: 10.1016/j.ecss.2013.12.030

de Vet, P. L. M., van Prooijen, B. C., Schrijvershof, R. A., van der Werf, J. J., Ysebaert, T., Schrijver, M. C., \& Wang, Z. B. (2018). The importance of combined tidal and meteorological forces for the flow and sediment transport on intertidal shoals. Journal of Geophysical Research: Earth Surface, 123(10), 2464-2480. doi: 10.1029/2018JF004605

Demarest, J. M., \& Kraft, J. C. (1987). Stratigraphic record of quaternary sea levels: implications for more ancient strata. The Society of Economic Paleontologists and Mineralogists, 223-239.

Dyer, K. R., Christie, M. C., \& Wright, E. W. (2000). The classification of intertidal mudflats. Continental Shelf Research, 20, 1039-1060. doi: 10.1016/ S0278-4343(00)00011-X

Griffioen, J., Klaver, G., \& Westerhoff, W. E. (2016). The mineralogy of suspended matter, fresh and cenozoic sediments in the fluvio-deltaic rhinemeuse-scheldt-ems area, the netherlands: An overview and review. Netherlands Journal of Geosciences, 95(1), 23-107. doi: 10.1017/njg.2015.32

Harris, P. T., \& Collins, M. (1988). Estimation of annual bedload flux in a macrotidal estuary: Bristol channel, uk. Marine Geology, 83(1-4), 237-252. doi: 10.1016/0025-3227(88)90060-6

Herman, P. M. J., Middelburg, J. J., \& Heip, C. H. R. (2001). Benthic community structure and sediment processes on an intertidal flat: results from the ecoflat project. Continental shelf research, 21(18-19), 2055-2071. doi: 10.1016/S0278-4343(01)00042-5 
Hibma, A., de Vriend, H. J., \& Stive, M. J. F. (2003). Numerical modelling of shoal pattern formation in well-mixed elongated estuaries. Estuarine, Coastal and Shelf Science, 57(5), 981-991. doi: 10.1016/S0272-7714(03)00004-0

Holland, A. F., Zingmark, R. G., \& Dean, J. M. (1974). Quantitative evidence concerning the stabilization of sediments by marine benthic diatoms. Marine Biology, 27(3), 191-196. doi: 10.1007/BF00391943

Jerolmack, D. J., \& Paola, C. (2010). Shredding of environmental signals by sediment transport. Geophysical Research Letters, 37, L19401. doi: 10.1029/ 2010GL044638

Kromkamp, J., Peene, J., van Rijswijk, P., Sandee, A., \& Goosen, N. (1995). Nutrients, light and primary production by phytoplankton and microphytobenthos in the eutrophic, turbid westerschelde estuary (the netherlands). Hydrobiologia, 311(1-3), 9-19. doi: 10.1007/BF00008567

Lanzoni, S., \& D'Alpaos, A. (2015). On funneling of tidal channels. Journal of Geophysical Research: Earth Surface, 120(3), 433-452. doi: 10.1002/ 2014JF003203

Le Hir, P., Cayocca, F., \& Waeles, B. (2011). Dynamics of sand and mud mixtures: a multiprocess-based modelling strategy. Continental Shelf Research, 31(10), S135-S149. doi: 10.1016/j.csr.2010.12.009

Le Hir, P., Monbet, Y., \& Orvain, F. (2007). Sediment erodability in sediment transport modelling: can we account for biota effects? Continental Shelf Research, 27(8), 1116-1142. doi: 10.1016/j.csr.2005.11.016

Lesser, G. R., Roelvink, J. A., van Kester, J. A. T. M., \& Stelling, G. S. (2004). Development and validation of a three-dimensional morphological model. Coastal engineering, 51(8-9), 883-915. doi: 10.1016/j.coastaleng.2004 .07 .014

Leuven, J. R. F. W., de Haas, T., Braat, L., \& Kleinhans, M. G. (2018). Topographic forcing of tidal sand bar patterns for irregular estuary planforms. Earth Surface Processes and Landforms, 43(1), 172-186. doi: 10.1002/esp .4166

Lokhorst, I. R., Braat, L., Leuven, J. R. F. W., Baar, A. W., van Oorschot, M., Selakovic, S., \& Kleinhans, M. G. (2018). Morphological effects of vegetation on the tidalfluvial transition in holocene estuaries (Vol. 6) (No. 4). doi: 10 .5194/esurf-6-883-2018

Maan, D. C., van Prooijen, B. C., Zhu, Q., \& Wang, Z. B. (2018). Morphodynamic feedback loops control stable fringing flats. Journal of Geophysical Research: Earth Surface, 123(11), 2993-3012. doi: 10.1029/2018JF004659 
Martinius, A. W., \& van den Berg, J. H. (2011). Atlas of sedimentary structures in estuarine and tidally-influenced river deposits of the rhine-meuse-scheldt system. Houten, The Netherlands: European Association of Geoscientist \& Engineers. (ISBN 978-90-73834-11-8)

McLaren, P. (1994). Sediment transport in the westerschelde between baarland and rupelmonde (Tech. Rep.). Cambridge, United Kingdom: GeoSea Consulting.

Mudd, S. M., D'Alpaos, A., \& Morris, J. T. (2010). How does vegetation affect sedimentation on tidal marshes? investigating particle capture and hydrodynamic controls on biologically mediated sedimentation. Journal of Geophysical Research, 115, F03029. doi: 10.1029/2009JF001566

Paola, C., Ganti, V., Mohrig, D., Runkel, A. C., \& Straub, K. M. (2018). Time not our time: Physical controls on the preservation and measurement of geologic time. Annual Review of Earth and Planetary Sciences, 46, 409438. doi: 10.1146/annurev-earth-082517-010129

Paree, E., \& Burgers, G. (2017). Toelichting op de zoute ecotopenkaart westerschelde 2016 (Rapport). The Netherlands: Rijkswaterstaat.

Partheniades, E. (1965). Erosion and deposition of cohesive soils. Journal of the Hydraulics Division, 91(1), 105-139.

Pierik, H. J., Cohen, K. M., \& Stouthamer, E. (2016). A new gis approach for reconstructing and mapping dynamic late holocene coastal plain palaeogeography. Geomorphology, 270, 55-70. doi: 10.1016/j.geomorph.2016.05.037

Pierik, H. J., Cohen, K. M., Vos, P. C., van der Spek, A. J. F., \& Stouthamer, E. (2017). Late holocene coastal-plain evolution of the netherlands: the role of natural preconditions in human-induced sea ingressions. Proceedings of the Geologists' Association, 128(2), 180-197. doi: 10.1016/j.pgeola.2016.12.002

Plancke, Y., Beirinckx, K., Liek, G. J., Vos, G., \& Schrijver, M. (2014). A new disposal strategy in the westerschelde, conciliating port accessibility and nature..

Rijkswaterstaat. (2009). Open earth, sediment atlas waddenzee. Retrieved from http://opendap.deltares.nl/thredds/fileServer/opendap/ rijkswaterstaat/sedimentatlas\_waddenzee/korrel.nc

Rijkswaterstaat. (2017). Waterinfo. Retrieved from https://waterinfo.rws . $\mathrm{nl}$

Sanford, L. P. (2008). Modeling a dynamically varying mixed sediment bed with erosion, deposition, bioturbation, consolidation, and armoring. Computers $\& 3$ Geosciences, 34(10), 1263-1283. doi: 10.1016/j.cageo.2008.02.011 
Sanford, L. P., \& Halka, J. P. (1993). Assessing the paradigm of mutually exclusive erosion and deposition of mud, with examples from upper chesapeake bay. Marine Geology, 114(1-2), 37-57. doi: 10.1016/0025-3227(93)90038-W

Santermans, J. (2013). Baggeren en storten - instandhouding vaarpassen schelde milieuvergunningen terugstorten baggerspecie (Achtergrondrapport A-31 No. I/RA/11387/12.333/JSN). International Marine \& Dredging Consultants, Deltares, Svasek Hydraulics and ARCADIS: Vlaams nederlandse Schelde commissie.

Savenije, H. H. G. (2015). Prediction in ungauged estuaries: An integrated theory. Water Resources Research, 51(4), 2464-2476. doi: 10.1002/ 2015WR016936

Schrijvershof, R., \& de Vet, L. (2018). Morfologisch modelleren plaatrandstortingen plaat van walsoorden (Rapport). Delft, The Netherlands: Deltares. (1230096-000)

Singer, A., Schückel, U., Beck, M., Bleich, O., Brumsack, H. J., Freund, H., ... Krncke, I. (2016). Small-scale benthos distribution modelling in a north sea tidal basin in response to climatic and environmental changes (1970s-2009). Marine Ecology Progress Series, 551, 13-30. doi: 10.3354/meps11756

van de Lageweg, W. I., Braat, L., Parsons, D. R., \& Kleinhans, M. G. (2018). Controls on mud distribution and architecture along the fluvial-to-marine transition. Geology, 46(11), 971-974. doi: 10.1130/G45504.1

van de Lageweg, W. I., van Dijk, W. M., Box, D., \& Kleinhans, M. G. (2016). Archimetrics: a quantitative tool to predict three-dimensional meander belt sandbody heterogeneity. The Depositional Record, 2(1), 22-46. doi: 10.1002/ $\operatorname{dep} 2.12$

van den Berg, J. H., Jeuken, C. J. L., \& van der Spek, A. J. F. (1996). Hydraulic processes affecting the morphology and evolution of the westerschelde estuary. Estuarine Shores: Evolution, Environments and Human Alterations. John Wiley, London, 157-184.

van der Spek, A. J. F. (1997). Tidal asymmetry and long-term evolution of holocene tidal basins in the netherlands: simulation of palaeo-tides in the schelde estuary. Marine Geology, 141(1-4), 71-90. doi: 10.1016/ S0025-3227(97)00064-9

van der Wal, D., van Kessel, T., Eleveld, M. A., \& Vanlede, J. (2010). Spatial heterogeneity in estuarine mud dynamics. Ocean Dynamics, 60(3), 519-533. doi: $10.1007 / \mathrm{s} 10236-010-0271-9$

van der Wegen, M., \& Roelvink, J. A. (2012). Reproduction of estuarine bathymetry by means of a process-based model: Western scheldt case study, the netherlands. Geomorphology, 179, 152-167. doi: 10.1016/j.geomorph .2012 .08 .007 
van Dijk, W. M., Cox, J., Leuven, J. R. F. W., Cleveringa, J., Taal, M., \& Hiatt, M. (2019). The vulnerability of tidal flats and multi-channel estuaries to dredging and disposal. EarthArXiv. doi: 10.31223/osf.io/67wxg

van Dijk, W. M., Hiatt, M., van der Werf, J., \& Kleinhans, M. G. (2018). Effect of perturbations by shoal margin collapses on the morphodynamics of a sandy estuary. EarthArXiv preprint. doi: 10.31223/osf.io/zpv8q

van Dijk, W. M., Mastbergen, D. R., van den Ham, G. A., Leuven, J. R. F. W., \& Kleinhans, M. G. (2018). Location and probability of shoal margin collapses in a sandy estuary. Earth Surface Processes and Landforms, 43(11), 23422357. doi: $10.1002 /$ esp.4395

van Kessel, T., Spruyt-de Boer, A., van der Werf, J., Sittoni, L., van Prooijen, B., \& Winterwerp, H. (2012). Bed module for sand-mud mixtures [Computer software manual]. Delft, The Netherlands. (1200327-000-ZKS-0013)

van Kessel, T., Vanlede, J., \& de Kok, J. (2011). Development of a mud transport model for the scheldt estuary. Continental Shelf Research, 31(10), S165-S181. doi: 10.1016/j.csr.2010.12.006

van Ledden, M., van Kesteren, W. G. M., \& Winterwerp, J. C. (2004). A conceptual framework for the erosion behaviour of sand-mud mixtures. Continental Shelf Research, 24(1), 1-11. doi: 10.1016/j.csr.2003.09.002

van Ledden, M., \& Wang, Z. (2001). Sand-mud morphodynamics in an esetuary. In 2nd symposium on river, coastal and estuarine morphodynamics (pp. 505514). Obihiro, Japan.

van Ledden, M., Wang, Z. B., Winterwerp, H., \& de Vriend, H. (2004). Sandmud morphodynamics in a short tidal basin. Ocean Dynamics, 54(3-4), 385391. doi: 10.1007/s10236-003-0050-y

van Maren, D. S., Oost, A. P., Wang, Z. B., \& Vos, P. C. (2016). The effect of land reclamations and sediment extraction on the suspended sediment concentration in the ems estuary. Marine Geology, 376, 147-157. doi: 10.1016/j.margeo.2016.03.007

van Rijn, L. C. (2007a). Unified view of sediment transport by currents and waves. i: Initiation of motion, bed roughness, and bed-load transport. Journal of hydraulic engineering, 133(6), 649-667. doi: 10.1061/ (ASCE)0733-9429(2007)133:6(649)

van Rijn, L. C. (2007b). Unified view of sediment transport by currents and waves. ii: Suspended transport. Journal of hydraulic engineering, 133(6), 668-689. doi: 10.1061/(ASCE)0733-9429(2007)133:6(668)

van Rijn, L. C. (2018). Literature review of critical bed-shear stresses for mudsand mixtures (Rapport). The Netherlands: www.leovanrijn-sediment.com. 
van Straaten, L. M. J. U. (1960). Aerial photographs. In J. H. van Voorthuysen \& P. H. Kuenen (Eds.), Das ems-estuarium (nordsee) (pp. 37-38). 'sGravenhage, Netherlands: Verhandelingen van het Koningklijk Nederlansch Geologisch-Mijnbouwkundig Genootschap.

van Straaten, L. M. J. U., \& Kuenen, P. H. (1957). Accumulation of fine grained sediments in the dutch waddensea. Geologie en Mijnbouw, 19(8), 329-354.

Vroom, J., de Vet, L., \& van der Werf, J. (2015). Validatie waterbeweging delft3d-nevla model westerscheldemonding (Tech. Rep.). Deltares, Nederland: Rapport 1210301-001-ZKS-0001.

Waeles, B., Le Hir, P., Lesueur, P., \& Delsinne, N. (2007). Modelling sand/mud transport and morphodynamics in the seine river mouth (france): an attempt using a process-based approach. Hydrobiologia, 588(1), 69-82. doi: 10.1007/ s10750-007-0653-2

Wang, Z. B., Jeuken, M. C. J. L., Gerritsen, H., de Vriend, H. J., \& Kornman, B. A. (2002). Morphology and asymmetry of the vertical tide in the westerschelde estuary. Continental Shelf Research, 22(17), 2599-2609. doi: 10.1016/S0278-4343(02)00134-6

Weerman, E. J., van de Koppel, J., Eppinga, M. B., Montserrat, F., Liu, Q. X., \& Herman, P. M. J. (2010). Spatial self-organization on intertidal mudflats through biophysical stress divergence. The American Naturalist, 176(1), E15E32. doi: $10.1086 / 652991$

Wiggers, A. J. (1960). Die korngrossenverteilung der holozanen sedimente im dollart-ems-estuarium. In J. H. van Voorthuysen \& P. H. Kuenen (Eds.), Das ems-estuarium (nordsee) (pp. 111-133). 's-Gravenhage, Netherlands: Verhandelingen van het Koningklijk Nederlansch Geologisch-Mijnbouwkundig Genootschap.

Winterwerp, J. C., Cornelisse, J. M., \& Kuijper, C. (1993). A laboratory study on the behavior of mud from the western scheldt under tidal conditions. Coastal and estuarine studies, 295-295.

Yallop, M. L., de Winder, B., Paterson, D. M., \& Stal, L. J. (1994). Comparative structure, primary production and biogenic stabilization of cohesive and non-cohesive marine sediments inhabited by microphytobenthos. Estuarine, Coastal and Shelf Science, 39(6), 565-582. doi: 10.1016/S0272-7714(06) 80010-7 